\title{
Chapter 4 \\ Experience with Digital Tools in Different Types of e-Participation
}

\author{
Georg Aichholzer and Gloria Rose
}

\begin{abstract}
The chapter offers a systematic overview of the use of digital tools for various forms of political participation and the experiences made so far, based on an extensive literature review. Discerning three key functions of e-participationmonitoring, agenda-setting and input to decision-making-the authors review a variety of formally institutionalised mechanisms as well as informal expressions of civic engagement, including social media. The examination of digital tool use for monitoring purposes extends from electronic information access and exchange to e-deliberation, while the role for agenda-setting mainly includes uses for e-petitions and e-campaigning, showing a mixed picture of democratic impacts. The review of e-participation providing input for decision-making focusses on e-consultations, e-participative budgeting and e-voting, identifying several persisting problems with the latter instrument. A special section examines e-participation at EU-level, from deliberative citizens' involvement projects and e-consultation to the European Citizens' Initiative (ECI) and e-petitions to the European Parliament. Findings show that digital tools enhance direct and participative democracy in many respects; however, exaggerated expectations of new democratic potentials remain unfulfilled: deliberative participative designs lack any impact on decision-making, and the ECI still is rather an instrument for civil society mobilisation than citizen empowerment.
\end{abstract}

\subsection{Three Basic Functions of e-Participation}

Understanding "e-participation" as the use of digital tools for political participation in the wider sense includes a wide variety of formally institutionalised mechanisms, as well as informal expressions of civic engagement. According to their predominant function in the policy cycle, we can discern three basic functions of participation (we prefer this typology because of the focus on level of impacts):

G. Aichholzer $(\bowtie) \cdot G$. Rose

Institute of Technology Assessment, Austrian Academy of Sciences, Vienna, Austria

e-mail: aich@oeaw.ac.at; gloria.rose@ oeaw.ac.at 
1. Monitoring: A basic category of participatory activities comprises monitoring and control of political processes, actors and decisions via access to relevant digital information (e-information), online deliberation and discussion (e-deliberation). Information is of course also relevant to all other functions of participation, however, a condition sine qua non for enabling monitoring and control.

2. Agenda setting: A second category may also start with accessing politically relevant information and discussing political issues but extends to activities such as mobilising support for political projects (e-campaigning) and submitting formal requests to government institutions (e-petitions).

3. Decision-making: Finally, providing cognitive or evaluative input to political decisions (e-consultation), setting priorities for or determining budget expenditure (e-participatory budgeting) and casting votes on political alternatives (e-voting) comprise a third type of e-participation.

Before we focus on these three basic functional categories and relevant sub-types of e-participatory activities within each, we will start this section with some overall assessments on the use and effects of digital tools for democratic processes.

Despite the long history of digital or e-democracy, the implementation of digital tools for political participation on a broader scale has come at a much slower pace than the expansion of e-government, i.e. electronic services in the public sector. Mahrer and Krimmer (2005: 38 ff.) speculate about fear of change and latent as well as overt opposition amongst politicians in legislative government branches as inhibiting forces, based on a study in Austria: "[. . . ] the very same parliamentarians who would be responsible for introducing new forms of citizens' participation for political decision-making are explicitly and implicitly opposing these reforms". Various earlier assessments of experiences with e-democracy provide a reference for an update with the most recent evidence.

Striking a balance after 25 years of e-democracy, van Dijk concluded that the primary achievement of digital democracy was a significant improvement in access to and exchange of politically relevant information. However, most disappointing from the perspective of direct democracy, "no perceivable effect of these debates on decision-making of institutional politics" was detected (van Dijk 2012: $53 \mathrm{ff}$.). The general conclusion then was that e-participation is largely confined to the initial and the final stages of the policy cycle (agenda setting, policy preparation, policy evaluation), and that it rarely allows for entries into the core stages of decisionmaking and policy execution. It was also found that bottom-up initiated e-participation was more successful than top-down initiatives and that the required set of digital skills was one of the greatest barriers to an effective enhancement of participation. In addition, Lindner (2012) finds the balance of empirical research on the use of e-participation sobering and could determine no evidence of increased and more inclusive participation to date. Though he acknowledges increased information transparency, the Internet's function to support critical monitoring and control and the extension of communication of political institutions with citizens, he deems the e-petitioning, e-consultation and online discussion platforms offered as being rather marginal in terms of power. Santos and Tonelli's conclusions (2014) largely tend to echo the general thrust of these findings. 
A meta-analysis of e-participation research by Medaglia (2011), covering 123 articles from April 2006 to March 2011, determined that the field was very dynamic in those years. One of the most noticeable developments was a shift from research on activities towards impacts and evaluations. No great attention was paid to the areas of e-activism, e-campaigning and e-petitioning during this time. E-voting, however, was experiencing increasing interest, though publications in this area tend to be about design proposals. Medaglia emphasises a "need to move beyond a technological perspective, encouraging the ongoing shift of research focus from government to citizens and other stakeholders" (Medaglia 2012: 346; see also Medaglia 2011: 99).

Panopoulou et al. (2014) attempted to determine what the success factors for e-participatory projects are. Having reviewed literature on e-government and e-participation success, Panopoulou and her colleagues went on to conduct a survey of practitioners across Europe. Success factors which were brought up by all three sources, namely, the e-government and e-participation literature as well as the surveyed practitioners, were as follows: management and planning, security and privacy, sustainability, addressing the digital divide and inclusivity, meeting user needs and expectations, government or management support, technological advances and good practice, a promotion plan and value for citizens as well as for the government or organisations. From the practitioners' perspective value for citizens, user needs and expectations, promotion plan, support from government/ management, management and planning and attention to digital divide issues are of highest priority (Panopoulou et al. 2014: 203). Based on the results of the literature and practitioner surveys, the researchers propose an e-participation success factor model including specific activities associated with the identified success factors (see Panopoulou et al. 2014: 204-205).

On the question of effects of e-participation, Font et al. (2016) took a closer look at what proposals resulting from participatory processes in Spain ended up being implemented, by studying 611 proposals from 39 different processes. The results are rather positive regarding implementation, with the team categorising a third of the proposals as having been fully implemented, another third partially implemented (e.g. with amendments) and a third not being implemented at all. Their assessment of accountability, however, concluded that in most cases there are no explanations given as to why certain amendments were made to the proposals or why proposals were not implemented, an area which could certainly use improvement. Font et al. (2016) determined that a participatory mechanism has a strong influence on the successful implementation of proposals, finding that "[. . . the odds that a proposal emerging from a participatory budget or other permanent mechanisms (e.g. citizen councils) is fully implemented double those of proposals coming out from a case of strategic planning or other temporary processes" (Font et al. 2016: 18). The team also notes that the processes which were categorised as fully implemented had short proposal lists.

A crucial, largely latent but decisive factor influencing the use of digital tools for political participation is trust. Scherer and Wimmer (2014) conducted a literature review of trust in e-participation, referencing Im et al. (2014) as having found a negative relationship between general Internet use and trust in government, but 
voicing hope in the possibility that e-government may mitigate these effects. Grimmelikhuijsen and Meijer (2014) are quoted as saying they did not determine there to be a positive relationship between transparency and perceived trustworthiness. Within the literature review, Kim and Lee (2012) are noted as discovering an increase of trust in local government as a result of positive experiences regarding government responsiveness quality and e-participation application usefulness. Another interesting insight by Wang and Wan Wart (2007) is brought up within the review, namely, stating that participation events resulting merely in consensus building will not increase public trust, but situations in which services the public wants can be achieved, public trust can be increased (Wang and Wan Wart 2007: 276 as quoted by Scherer and Wimmer 2014: 63). Services which are of specific interest to citizens and therefore enjoy much citizen involvement are zoning and planning, parks and recreation as well as policing and public safety (Wang and Wan Wart 2007: 273).

The next subchapters will present the main results and insights gathered from the literature, structured into the three basic categories of monitoring, agenda setting and decision-making as well-related types of participatory activities (e-information, e-deliberation, e-petitions, e-campaigning, e-consultation, e-budgeting and e-voting), followed by a separate subchapter on experiences with the main participatory instruments in use at EU level.

\subsection{Monitoring}

\subsubsection{E-information}

Barber's seminal contribution to the idea of participatory democracy regarded "equalizing access to information" (1984: 276) as one of the greatest potentials of interactive technologies and proper information as a principal precondition for political judgement and active participation as a responsible citizen. Indeed, according to van Dijk's (2012) assessment, the greatest achievement was much better access to political and government information, meaning provision, retrieval and exchange between governments and citizens, but also public administrations, representatives and political and community organizations. Professional information brokers, journalists and sufficiently educated citizens have profited most from the content available on governmental and NGO websites and portals, public information systems, campaign sites of parties and candidates, weblogs, voter guides, online newspapers, journals and web-TV channels (van Dijk 2012: 53 ff.).

Access to e-information holds special relevance for the monitoring citizen. Monitoring by citizens is envisioned to be a way of ensuring state accountability and is the prerequisite for citizens to contest or question political decisions made. TheyWorkForYou.com is an example of parliamentary monitoring employed in the UK, meant to provide access to neutral and nonpartisan information on activities of Members of Parliament (MPs) (Escher 2011). A similar tool is provided by the 
platform abgeordnetenwatch.de in Germany. According to Rumbul (2014), however, monitoring the amount of times MPs spoke in the chamber led to an increase of statements from MPs which contained little relevant content. Such cases reveal significant gaps in current monitoring tools.

The importance of a quantum leap in improved access to information cannot hide the deficit regarding opportunities for democratic participation in more influential forms at different levels of government. For example, at national level such as in Portugal where e-participation initiatives are sparse, with the function of most initiatives at the local level being to inform, as the government primarily supports e-informing rather than e-consulting and e-collaborative efforts (Fedotova et al. 2012). This lack of effective e-participation is not restricted to Portugal, however, with Boussaguet (2016) making similar claims about participatory mechanisms at the EU level, criticising the lack of use of participatory experiments or tools and the failure to include "ordinary" citizens.

\subsubsection{E-deliberation}

Deliberation, understood as careful reflection and exchange of arguments on a specific issue to arrive at considered judgement, is a basic element behind the idea of deliberative democracy. A deliberative process thus involves both an individual and collective activity. Its democratic relevance is not only to improve the quality of public decisions but also to participate in reaching decisions about what actions to take. "It orients toward understanding, thoughtful reflection, mutual respect, and much more, but it points toward a final decision-making stage" (Gastil 2013: 218). Before diving into the subject of e-deliberation, it is perhaps appropriate to repeat the words of Coleman and Moss (2012), that "[ . . ] there exists no scholarly consensus about what even the most basic characteristics of deliberation are, and scholars are leading players in the effort to construct a meaning that is sufficiently compelling to relate the notion of deliberative citizenship to the empirical world around them" (Coleman and Moss 2012: 5). This lack of consensus must be kept in mind when examining research results.

In order for deliberative civic engagement processes to be successful, one needs the engagement of public officials and politicians (Barrett et al. 2012). Structural components identified by Knobloch et al. (2013) as cultivating successful offline deliberation are deliberative skills training and a mix of discussion formats and extended question-answer sessions. When regarding offline deliberative civic engagement processes, Weiksner et al. (2012: 3) observe that they can lead to short, medium as well as long-term policy impacts. Deliberative formats enjoy high citizen interest, can be cost-effective and superior to conventional processes concerning the inclusion of various viewpoints and coping with prejudices (Collingwood and Reedy 2012). Deliberative civic engagement can also prove helpful in situations where the citizenship is deeply divided, such as intercultural conflicts, though Siu and Stanisevski (2012) caution about its limitations and 
feasibility on a case-to-case basis. Contributions can also be made to community capacity (Kinney 2012; Weiksner et al. 2012). Knobloch and Gastil (2015) examined highly structured deliberative events (the Australian Citizens' Parliament and the Oregon Citizens' Initiative Review) and found civic transformation and increases in deliberative and internal efficacy as well as communicative and community-based engagement, with feelings of empowerment regarding politics and public life. In general, deliberative civic engagement seems to be of a more temporary nature, being employed for singular issues and spanning only a short amount of time, embeddedness in political decision-making and problem-solving routines being the exception rather than the rule (Leighninger 2012).

Common criticisms of deliberative systems include the prevalence of idealism, low motivation and aptitude as well as narrow-mindedness of citizens, the prioritising of purely reason-based argumentation, a lack of heterogeneous representation and a lack of impact on policymaking (Collingwood and Reedy 2012; Weiksner et al. 2012).

When comparing offline and online deliberation, Davies and Chandler (2013) find that voice deliberation in real-time is more effective than deliberations concluded through text, in particular regarding mutual understanding and opinion forming. On the other hand, they also find benefits of anonymity concerning the willingness to participate, but at the cost of satisfaction for the participants. Online discussions with deliberative design show increased positive individual-level outcomes compared to non-deliberatively designed online discussions, with these effects being most prominent in anonymous conditions: "[...] deliberative design positively affected participants' opinions and values, coherence, efficacy, and trust for institutions, but not generalized trust or readiness for political action" (Strandberg 2015: 466-468). The above-mentioned problems of deliberative systems concerning lack of heterogeneous representation are particularly pronounced in online deliberation, with a tendency to over-represent white males who are young and educated, as was found to be the case by Baek et al. (2012) in a comparison with face-to-face deliberations in the USA. On the related subject of unrepresentativeness, Davis observes the following: "Online discussants vary significantly from the general public demographically and in terms of media usage, political interest, political attitudes, and behavior" (Davis 2005: 124). It is due to this, that the public opinion is distorted in online spaces. Online discussions are nonetheless being used to draw conclusions about public mood, with reactions to events trickling in minutes after occurring.

It is, however, also possible for many alternative viewpoints to be included in deliberative processes, despite not achieving high representativeness. This was observed for a case study in Finland investigating a special format of online deliberation, so-called "crowdsourced deliberation", "[...] an open, asynchronous, depersonalized and distributed kind of online deliberation among self-selected participants in the context of an attempt by government or another organization to open up the policymaking or lawmaking process" (Aitamurto and Landemore 2016: 1). The process of the investigated case study had the character of democratic deliberation and covered many varying viewpoints, despite statistical 
representativeness not being given, showing that "lack of statistical representativeness thus does not necessarily mean poverty of views, information and arguments and low-quality deliberation" (Aitamurto and Landemore 2016: 2). Cho and Keum (2016) observed that political expression is also more independent of socioeconomic status on social networking sites than in offline political discussions, based on the findings of a national survey in the USA from 2012, whereby the individuals who use social networking sites for political purposes are also generally less affected by their social economic status, also regarding their offline discussions.

Another issue commonly raised with online deliberation concerns the quality of the discussions. Kersting (2013: 270) criticises the quality of online deliberative instruments as "[...] more oriented towards the construction of identity and community bulding than towards political dialogue and deliberation". He also finds that web forums "[...] are not argumentatively-respectful and consensus-oriented, but are often pure monologues and frequently aggressive" (Kersting 2005 as quoted in Kersting 2013: 277). His conclusion is a very critical view on online third spaces, mentioning lack of openness and exclusion as additional attributes next to selfaffirmation and in-group bonding, but sees a future in combining online and offline instruments. Online forums were also investigated by Loveland and Popescu (2011), who regarded the posts of five regional web forums hosted by a US newspaper. They were unconvinced of the quality of debates, noting that discussions remained for a large part unfinished and were of an episodic nature. Davis (2005) makes similar observations in his publication "Politics Online", concluding that online political discussions do not reflect opinions of the public, due to several reasons, above all obstacles in the environment for participation and the lack of representativeness. The problems of the environment are caused primarily by the lack of moderation and the lack of accountability. Social rules can be broken without consequences, oftentimes leading to chaos, hostile interactions and absence of rational argumentation. Another obstacle is audience fragmentation, typical for online environments due to specialised forums and groups. This leads to political talk being conducted within "own discussion ghettoes". "The individual poster seems less interested in engagement than in pronouncement. Opinions are set. The goal clearly is expression and reinforcement, not interaction and exchange" (Davis 2005: 123). Respectful conversations can, however, be ensured through a moderator, as was shown in the case of the Oregon Citizens' Initiative Review by Knobloch et al. (2013). Lampe et al. (2014) as well as Davies and Chandler (2013), Coleman and Moss (2012) and Weiksner et al. (2012) voice their support for a moderation system and structure to accompany online deliberations to ensure the quality of online discourse, which Lampe et al. estimate would even be possible for large-scale online political discussion spaces. For online environments, it is important to ensure that the online communicative environment matches the deliberative task at hand and is engaging and rich in media (Davies and Chandler 2013).

Despite the described shortfalls of discussion forums which can often be observed concerning quality and the culture of discourse, positive examples can also be found. According to the results of an analysis of three UK-based discussion forums from 2010 to 2014, Graham et al. (2016) claim that political actions can in some instances 
be cultivated in third spaces, such as online lifestyle community spaces. In order for political action to follow up on online discussions, the following factors are identified: a helpful and supportive culture or structure, framing topics in a personal manner or in connection to everyday life and communicating in an interactive and reciprocal community or platform. An investigation of online lifestyle community spaces highlights "[...] the importance of political talk for triggering both manifest and latent political participation" (Graham et al. 2016: 1383). Dunne (2015) examined 138 online forums dedicated to local politics regarding their impact and found none on direct democracy, as none of these forums provided any voting mechanism.

Mechant et al. (2012) report idea-generation and -evaluation strategies successfully working for two case studies of smart city applications in Belgium, applauding methods such as brainstorming sessions, online expert and end-user surveys and online crowdsourcing. Strandberg and Grönlund (2012), however, note few noticeable changes from a pilot citizen deliberation experiment carried out in Finland, mentioning knowledge gains and opinion changes but few other effects in the areas of political efficacy or interpersonal trust. Based on an examination of the Comparative National Elections Project (CNEP), a cross-national data set of 29 postelection national surveys, Torcal and Maldonado (2014) conclude that an interest in politics is not necessarily encouraged by political deliberation, but that effects such as political disengagement can also be entailed. While plural media information has a positive impact on political interest and political engagement, it is the exposure to personal discussions which carries the potential of detrimental effects. Interest and engagement are lowered when individuals are confronted with differing opinions on political subjects (see also Lu et al. 2016 as well as Guidetti et al. 2016).

An exploratory case study was done by Chadwick (2011) on the failure of an online citizen engagement initiative in "TechCounty". The case is particularly interesting because the conditions seemed ideal for a deliberative project, with the county being home to many individuals employed in technology fields and local political participation being relatively high, judging by election turnouts. The idea was to create an online forum meant to offer advice and house discussions on the topic of fostering and adoption provision, a topic where the likelihood of controversy was judged to be very low. An exchange of ideas and information was expected to lead to higher awareness of child welfare, improvements of the service and ultimately an increase of applications by individuals willing to foster or adopt. However, the project was a failure, running for not even a year before it was shut down. Very few people posted topics in the forum during this time, the number of discussions held were low, while maintenance by a private technology company was costly. Needless to say, the desired outcomes could not be achieved in the short run. Lessons can be drawn from the identified reasons for failure: "budget constraints and organizational instability; policy shifts inside the social service agency; political ambivalence among elected representatives; the perception of legal risks that led to a cautious depoliticized approach; and problems generated by the outsourcing of part of the initiative" (Chadwick 2011: 27). 


\subsection{Agenda Setting}

\subsubsection{E-campaigning}

Campaigns are described by Baringhorst (2009: 10) as "[...] a series of communicative activities undertaken to achieve predefined goals and objectives regarding a defined target audience in a set time period with a given amount of resources", whereby attention is called to the fact that the high variety of campaign types makes the term difficult to define. Consequently, our case studies in Part II of this book will only exemplify a small selection, especially bottom-up types of practices with potential for agenda setting. Campaigns can also be seen as strategically coordinated collective activities that seek the engagement and multiplication of followers, aiming to push specific topics (e.g. climate protection) and to put them on the political agenda. The main agents of campaigning activities are various civil society actors and political parties. Lindner et al. (2016) have shown how the first category profits from the advantages of digital networked environments and the wide variety of available tools (e.g. mailing lists, blogs, YouTube videos, discussion fora, wikis, social media) and how the Internet extends the repertoire of collective action, both regarding information and framing and as a tactical medium in political campaigning. Regarding the recent Gilet Jaune movement in France, social media have proven to be an essential tool. Another very recent example of extraordinary public attention raised is the case of the "youtuber"Rezo's activities in the run-up to the European elections 2019 in Germany. ${ }^{1}$ His direct attacks, particularly against the conservative party CDU, may have substantially contributed to the high losses of votes especially amongst the younger voters, although the exact effect is difficult to determine. $^{2}$

E-campaigning by political parties is expanding likewise, particularly including the role of social media. In recent years much literature has appeared on the use of digital tools for electoral campaigning, investigating the importance of social media during various national elections (see below). Regarding the use of digital tools with participatory objectives by politicians, Medaglia notes: "The use of social network services, for instance, is paradoxically found to reflect the one-way communication structures of traditional political campaigning, and not to foster citizen involvement in decision-making (Andersen and Medaglia 2009) [...]" (Medaglia 2012: 352). This is in line with Baringhorst's observation that government actors tend to use campaigns for informational and educational purposes, while civil society actors typically campaign in an attempt to influence ongoing political debates or current political decisions, mobilising for certain activities and building up public pressure (2009: 12). E-campaigns can also aim to bring controversial issues onto the political

\footnotetext{
${ }^{1}$ https://www.theguardian.com/world/2019/may/22/german-youtuber-rezo-video-attackingmerkel-party-cdu-goes-viral, accessed 02.06.2019

${ }^{2}$ https://www.faz.net/aktuell/politik/europawahl/rezo-und-die-eu-wahl-wie-spd-und-cdu-diejungen-verloren-16210331.html, accessed 02.06.2019
} 
agenda, which can then be formally introduced into the political system through the means of e-petitions (Lindner et al. 2016: 93).

Recent developments have underlined that narrowcasting and political marketing as specific types of campaign strategies can have a big impact on representative democracy (Edwards and De Kool 2016). A combination of social and traditional media can effectively be employed for political marketing in which political parties disseminate news and reports themselves. Narrowcasting describes the formulation of specific messages which are tailored to a particular target group. This is again an area social media can be very helpful in. Through the use of social networks and targeted email campaigns a very specific group of individuals can be reached with specific information. The 2008 Obama campaign was a huge success precisely because it combined narrowcasting with centralised coordination (Towner and Dulio 2012). Along with the 2016 US presidential election, however, digital campaigning methods reached an unprecedented level of "computational propaganda" (Woolley and Howard 2016, 2018). The combination of microtargeting and "political bots as automated scripts designed to manipulate public opinion" on social media spread all sorts of misinformation (Howard et al. 2018: 81). It is controversial whether this effectively swayed the election result in Donald Trump's favour (cf. Liberini et al. 2018; Woolley and Guilbeault 2017; Allcott and Gentzkow 2017), or to what extent automation and labour market issues shaped the outcome, as Frey et al. (2018) suggest. However, "the 2016 campaign highlighted the challenges that the Internet poses for American democracy, and perhaps democracy in general" and "that virality is now the coin of the campaign realm"(Persily 2017: 71-72). These challenges became salient once more as the Cambridge Analytica scandal broke in March of 2018, revolving around a data breach affecting the personal data of millions of Facebook users. This directed a spotlight on how strategic use can be made of data harvested on social media platforms to influence public opinion. Individual personality profiles were constructed and in combination with an ensemble of different machine learning approaches highly personalised advertising based on personality data was enabled (Hern 2018). The scandal encouraged public discussions not only about privacy and consumer protection but also surrounding misinformation and propaganda, with the CEO of Facebook Mark Zuckerberg being asked to testify in front of the US Congress.

Political marketing and narrowcasting touch on the work of parliaments, because they help define the context in which parliamentary democracy operates. They turn public opinion into a compass with which representatives align the exercise of their mandate. This means that the nature of political representation is changing from a contractual relationship between electorate and elected to a relationship in a permanent state of flux, with politicians constantly being challenged to determine their position vis-à-vis public opinion. The traditional and new media are reinforcing this tendency and facilitating the strategic behaviour amongst politicians to which it is giving rise (Coleman and Spiller 2003). As a consequence, the two methods do little to encourage citizens and politicians to interact and confront each other's opinions.

Circumstances in Europe appear to be less conducive to effective narrowcasting than in the USA. Party discipline is weaker there than in Europe, leaving more scope 
for differentiated messages. It is riskier to disseminate isolated electoral messages in Europe (Ward et al. 2003; Cardenal 2011). Studies carried out in Norway, Germany and Austria show that political parties still make little use of online opportunities to connect with specific groups. This is in part because party strategists are unsure about the effects of narrowcasting (Karlsen 2011; Russmann 2011). Koc-Michalska et al. (2014) examined the 2007 French presidential campaign, along with the 2012 campaign, on the basis of two surveys and a quantitative content analysis of candidate websites. They determined that in 2012 social networking platforms appeared as a new online public sphere in which younger and less politically involved individuals, who are unsatisfied with the democratic system, partake. However, it also could be shown that prior political attitudes such as interest and trust remain decisive factors. Another observation the authors could make was that the personal homepages of minor and fringe parties have started to even outperform those of major candidates, despite the difference in resources.

\subsubsection{E-petitions}

E-petitions represent a category of participation opportunities for citizens that is formally institutionalised and fully operational at many government levels, from local communities to the European Parliament (Lindner and Riehm 2011). An e-petition system allows citizens to submit to a government institution a formal request on a specific political issue following a set of formal procedural rules, whereby all steps can be carried out online. Petitions are a hybrid category of participatory practice, since formal procedures are organised top-down but petitions on specific subjects are initiated bottom-up by citizens. The instrument is mainly related to the phases of problem definition, articulation and agenda setting in policymaking. It should be noted that the label "citizens' initiative" is used for a participatory mechanism that can be more or less the same as, or at least very similar to, a petition. One of the most well-known examples is the European Citizens' Initiative which will be treated separately in Sects. 4.5.3. and 9.1.

E-petitions can be an efficient tool to empower citizens and address common issues, given the process possesses a certain amount of transparency (Alathur et al. 2012). E-petitions exist in various forms: petitions that are merely electronically processed internally at the institution addressed; petitions submitted electronically (via email or web-interface); petitions that are publicly accessible on the Internet and provide more or less additional information; and publicly accessible e-petitions that include extended communicative and participatory functionalities (Riehm et al. 2009, 40). E-petition tools, especially those implemented at national levels in Scotland and Germany, have been studied quite intensively. Most recent assessments (Bochel 2013; Riehm et al. 2014; Lindner and Riehm 2011) add to earlier evaluations, amongst others, by the Office of Technology Assessment at the German Bundestag, the German parliament (TAB), where "Public (electronic) Petitions" were introduced in 2005. This type of petition tool comprises the following 
components: submission via email attachment; examination by the petitions committee; publication on the Internet; possibilities for co-signing and discussing petitions online; processing, examination and replies to the petitioners; and publication of the decision on the Internet. Only those petitions that pass the examination by the petitions committee are published; during the pilot stage they amounted to only $2 \%$ (Riehm et al. 2009, 27).

The system of public electronic petitions at the German Bundestag enjoys much popularity and is deemed a success; the percentage of e-petitions amongst all petitions increased from $17 \%$ to $34 \%$, and public petitions grew from 5\% to $24 \%$ between 2006 and 2011 (Riehm et al. 2014: 9-18, 26-28). During this period more than 4 million people signed 2750 public electronic petitions and an accumulated total of more than 200,000 discussion contributions were recorded. The petitioners and the petitions committee are given the opportunity to discuss the issue jointly in a public committee meeting if over 50,000 people sign a petition. This innovation is seen positively by both petitioners and members of parliament. The vast majority also welcomes the implementation of discussion fora and finds them informative and objective. The petitions committee considers that between one third and a half of the petitions are positively concluded. Petitioners themselves are a little more critical: only one third were satisfied with the treatment of their petition.

A common observation reflected in this case study is that e-petitions do not typically mobilise new citizens to participate via petitions, but they tend to substitute conventional petitions, leading to no overall growth in petitioning activities. The average petitioner remains male and with a higher educational background than average citizens, with e-petitioners being younger than conventional petitioners. The move to the Internet alone does not lead to procedural transparency and increased participation opportunities. This is more likely in a combination of technological and politico-institutional reform, as was the case in Germany.

In England, Panagiotopoulos et al. (2011) examined the effectiveness of e-petitioning tools in English Local Government and came to a less optimistic conclusion, claiming the efforts of institutional compliance to be minimal and the actual use of e-petitions to be low. Often governments fail to provide official replies to petitions which hit their quota, or they take far too long to issue these replies until the matter at hand is of no more relevance (Wright 2012, 2016).

The case of the Downing Street e-petitions (UK) was widely lauded as a success and led to a wider adoption of e-petitioning processes (Wright 2012). However, it suffered from highly unequal participation. This was in part due to the high presence of so-called "super-posters", who either create more than ten accepted petitions or sign over 100 petitions. "The regular petition creators were particularly harmful because they posted on new topics quickly, and Downing Street would block subsequent petitions on similar topics. Many thousands of people attempted to become active citizens only to find their petition (and often several) rejected. However, the rule that blocked repeat petitions limited the chance for people to dominate the agenda [...] while still allowing people to set their own" (Wright 2012: 466). Wright further criticised the lack of a formal space to deliberate or counterpetition. El Noshokaty et al. (2016) examined what makes an e-petition successful 
and came to the conclusion that incorporating positive emotions into a petition will raise its chances of success. No changes in success rate could be observed in petitions with an emphasis on moral obligations. In fact, in petitions where moral and cognitive elements were very strong, El Noshokaty et al. (2016) even noted a decline in success rates. Petition quality also factors into success. In the case of a government-initiated programme in China, most attention and comments are granted to petitions with high salience and low complexity (Zhang et al. 2016). Despite its popularity amongst citizens, this case is criticised for the prevalence of so-called "participation chaos", stemming from low-quality proposals with little or no relevance and organisational issues such as misplacements of proposal types, whereas organised participation requires a certain level of civic knowledge or skills (Zhang et al. 2016). Analysing the growth of the Downing Street e-petitions with a big data approach (over 8000 petitions) over a time span of 2 years, Hale et al. (2013) discovered a few successful petitions with rapid growth, the number of signatures gathered on the first day being a good indicator for success.

But how do the petitioners themselves define the success of a petition? According to Wright (2016), citizens can perceive petition success in a number of additional ways to policy impact, such as the following: increased publicity/awareness, increased membership, increased credibility, galvanised/focussed support, sense of solidarity in local/national community, feeling of making a difference, show of acting, policy changes through government, government provided alternatives or partial changes, helped gain key support/links, helped gain access to ministers, got an official response, reached a set target of signatures, increased understanding in government and/or amongst general public, made a statement, were able to express concerns, fulfilled sense of civic duty, proved others also care about the issue (Wright 2016: 850).

Researchers in Sweden examined the relationship of e-petitions on trust in political institutions with survey data, seeing as e-petitions are considered one of the most commonly used variants of citizen participation and concluded: "In general, experiences with e-petitioning have not rendered any overall gain in trust; and for citizens more distant from the political mainstream, distrust is often reinforced. However, the results show that more citizens with a negative predisposition toward government have changed their perception in a positive direction than vice versa (positive predisposition-negative change). So even if negative reinforcement is more common than positive reinforcement, change is more positive than negative" (Åström et al. 2016: 3f.).

Largely positive experiences with another tool for e-petitions have also been reported in the context of the New Citizens' Initiative Act in Finland (see Lironi 2016, 18 ff.). Since its institutionalisation in 2012, nine successful initiatives reached the Parliament. Of these only one was translated into law so far. The main experiences were as follows: enhanced participation of citizens in policymaking, especially amongst the youth; mutual learning processes amongst citizens and decisionmakers; policy-shaping new ideas brought in by citizens; and enhanced legitimacy of policymaking. However, this instrument rather mobilises already privileged groups than a more representative section of the society, and although it raised the 
level of trust in policymaking, there were also signs of political disenchantment, especially amongst the supporters of failed initiatives.

E-petitions systems can also lead to so-called "slacktivism". The idea is that individuals engage in "activist" actions with minimal effort and no strong real-world consequences, the act itself only serving to satisfy a sense of having accomplished something and decreasing the likelihood of engaging in further, perhaps more effective, political engagements. Schumann and Klein (2015) could show negative effects of slacktivism on willingness to participate in a demonstration or to partake in a panel discussion, for example. They note the importance of individuals to feel part of a group and be invested in the group's welfare and viability in order to mobilise for offline collective actions.

Parycek et al. (2014) evaluated OurSpace, an international project dedicated to improving the engagement of the youth of Europe with European decision-makers through the combination of ICT use, information and motivation to participate. It turned out to be very difficult to mobilise young citizens. Participants felt sceptical regarding the potential to improve trust in politics, but recognised the value of OurSpace as a tool to contact politicians and present their opinions to decisionmakers. The research team also discovered Europe's youth to be "[...] very capable to engage in face-to-face and anti-hierarchal discussions with both politicians and other users, and to engage in respectful and inclusive deliberation online" (Parycek et al. 2014: 138). The engagement of decision-makers was an important factor in the success of the project, and the implementation of social features such as chat or profile options are advised. Identified barriers for discourse were language, navigational difficulties on the Internet platform and low interest in European-level matters.

\subsection{Decision-Making}

\subsubsection{E-consultation}

E-consultations belong to the group of top-down e-participation instruments most widely practised at all tiers of government-from the local to supra-national levels. In practice the function of this instrument may be confined to contribute to agenda setting but in principle it also carries potential to substantially shape decisions to be taken. Main objectives are to enhance the legitimacy of political decisions and to raise the quality of decisions by improving inputs as regards the social range and/or the knowledge base. The potential to rationalise political decision-making is typically activated in the phase of policy formulation (cf. Albrecht 2012: 13ff.). A variety of designs is being practised with e-consultations. In addition to open and closed consultations as basic categories the variants include simple question-andanswer discussion fora, e-polls or e-surveys, selected e-panels and so-called editorial consultations (e.g. participatory drafting of policy documents in the European Parliament's Citizens' Agora) (cf. Tomkova 2009). 
Pammett and Goodman (2013) explored the consultation practices undertaken before the use of e-voting systems as well as the following evaluation practices in Canada and Europe. They deem consultations important for openness and transparency in the context of e-voting to foster trust in the electoral process. In their assessment consultations are limited in various respects. While in Europe they tend to involve parliamentary or government committees, political parties, expert committees and specific stakeholder groups, consultations in Canada appear to transpire between city councilors and government officials and often adopt the character of informing about decisions already made rather than consulting on a decision before the fact. Regarding the organisation of e-consultations, Loukis and Wimmer (2012) observed that one can achieve higher-quality focussed debates by structuring the consultations. They warn, however, that introducing structure can also lead to reduced participation as well as the exclusion of specific groups, resulting in a quality-for-quantity trade-off. They propose that structured e-consultations should be introduced complementary to unstructured consultations already taking place on many government agency sites. An evaluation of the first e-consultation ever held by the Irish House of Parliament showed successes regarding the Parliamentary reform and the mobilisation of citizens to participate in policymaking processes. However, it assessed e-consultations still as "appendages to existing, centralized decision-making power" (Murray 2013: 1), rather than constituting a development in the direction of e-democracy. Similar to Loukis and Wimmer (2012), Murray also warns of the quality of participation, with a reference to lack of Internet accessibility for many individuals.

\subsubsection{E-participatory Budgeting}

A new instrument termed "participatory budgeting" has practically been invented in Porto Alegre, Brazil, where citizens have been participating in processes to determine the distribution and investment of municipal budgets since 1989. This participatory arrangement, classified and much celebrated as a democratic innovation, has attracted special attention because of its special origin and participation in decisionmaking. E-participatory budgeting stands for the further development of this model using electronic communication tools. Over the past 25 years the practice of participatory budgeting first spread in Brazil and Latin America and subsequently all over Europe, with several hundred cities adopting the concept (Talpin 2012: 186). With the diffusion of the model, a differentiation process into a number of sub-types took place. Today traditional, online or hybrid communication channels are practised (cf. Mkude et al. 2014; Miori and Russo 2011), with varying degrees of success (Röcke 2014). In a study of projects in 20 European cities, Sintomer et al. (2008) identified six different models. Not all cases give citizens decision-making power; some are merely consultative or can have other impacts, for example, contributing to the modernisation of public administration or bridging the gap between politicians and citizens. Unlike the original model in Porto Alegre, the European cases only deal 
with 1\%-20\% of the municipal budget (Talpin 2012: 186). In Germany, participatory budgeting phases mostly comprise general information, discussion of ideas, specification of selected proposals and voting on selected suggestions. These are predominantly not final binding decisions. They are taken by city or community councils, mostly without a specific budget included (cf. Schneider 2018). A combination of online and offline channels to maximise inclusiveness is now state of the art. Discussions on how to distribute public funds are challenging for all stakeholders and consume much time and resources. Proper process design and ICT support to save time and resource demands are therefore essential elements (Heidelberger 2009).

In Europe, Sintomer et al. (2008, 2010) identified the following impacts: support for the demand for increased transparency, improved public services, accelerated administrative operations, better cooperation amongst public administration units and enhanced responsiveness. Positive contributions to the political culture and competences of participants can also be expected. This can include extended participation opportunities, enhanced transparency of public policy, better quality of decision-making, increased legitimacy and a stronger identification with the local community. Cost reduction and major structural reforms are less likely achieved.

Participatory budgeting has been carried out in over 1700 local governments from over 40 different countries, according to Cabannes (2015). Improvements can be achieved in the areas of basic service provision and management, due to the element of community oversight. Goncalves (2013) observes increased investments in sanitation and health services in Brazil as a result, leading to reduced infant mortality and showing that it can indeed impact public expenditures with noticeable consequences. Moreover, it "[...] is an effective mechanism of local authorities influence on territorial development" (Volodin 2014: 378), as with co-managed slum upgrading in Porto Alegre (Pimentel Walker 2016). However, as Gordon et al. (2017) point out, social media platforms remain underused in participatory budgeting processes because local community leaders in the USA perceive a lack of adequate infrastructure and hindrances caused by restrictive policies, as well as security concerns, which could be limiting success.

Lim and Oh (2016) compared offline and online participation channels of a participatory budgeting system in Korea, determining that citizen opinions were ultimately incorporated in the resulting budget or policy decision-making, with offline systems having been more successful due to higher deliberativeness and representativeness.

\subsubsection{E-voting}

E-voting is the form of e-participation with the most direct influence on a decision, i.e. the outcome of a choice between alternative options. However, since elections are a cornerstone of democratic institutions, not only the outcomes are important but also the whole process of voting needs special attention and must fulfil certain 
criteria. Therefore, our case studies in Chap. 12 will include a special focus on process aspects. The composition of topics discussed in Lindner et al. (2016) is still valid and reflected in the literature. An update of empirical case analyses offers the most valuable knowledge for the purpose of this section. For instance, as Estonia was the first country to introduce Internet voting for national and binding elections (in 2005 on a local level and since then for all kinds of elections-local, national, European), it is often analysed and rather dominant in the recent literature (e.g. Heiberg et al. 2012; Kitsing 2014; Sál 2015; Springall et al. 2014; Vassil and Weber 2011; Vinkel 2012, Hall 2012; Kersting and Baldersheim 2004). Interestingly, this does not imply success in e-democracy in a broader sense (Toots et al. 2011).

Another popular case, due to its long history and well-embedded and long-term political strategy, is Switzerland (e.g. Beroggi et al. 2011; Driza-Maurer et al. 2012; Germann and Serdült 2014; Hill 2015; Serdült et al. 2015). In the case of Norway, the very high level of public trust in the government and the high degree of caution and professionalism that accompanied the introduction of Internet voting in 2011 raised hopes that it could be established there. Nevertheless, controversies over the sufficiency of security mechanisms led to a discontinuation of the Internet voting project in 2014. In addition to these prominent European cases, interesting insights can also be gained from experiences made with Internet voting around the world, e.g. in Australia or the USA. Analyses of all of these empirical cases, focussing on a variety of topics, such as trust, security and transparency or impact on voter turnout, contribute to gain well-grounded knowledge about the current state of Internet voting.

\subsubsection{Legal Theory and Computer Science}

The introduction of Internet voting is confronted with a number of legal challenges. Elections, being a key element of democracy (Garrone 2005: 111), have to be protected carefully. While a legally binding constitution defines the procedural requirements for elections, computer science is in charge of developing the measures that ensure compliance with these requirements (Bräunlich et al. 2013). The main election principles, namely, universal, equal, secret, direct and free suffrage, find their manifestation in national legal frameworks, as well as in international election standards, for instance, the European Commission's Compendium of International Electoral Standards (EC 2016), the Venice Commission (2003) or the OSCE Election Observation Handbook (2010). In addition, the Council of Europe's (2005) recommendations on the legal, operational and technical standards for e-voting (Rec (2004)11) state that "e-voting shall respect all the principles of democratic elections and referendums" (Council of Europe 2005: 7) and refer to those five principles of voting. In fact, the Rec(2004)11 has been and still is a very influential international document (Stein and Wenda 2014). Aspirations to update and renew $\operatorname{Rec}(2004) 11$ are discussed on a regular basis in review meetings or expert meetings of the Council of Europe. 
Compliance with these central legal principles poses great technical challenges for the implementation of Internet voting. Fundamental Internet security problems need to be taken seriously, and procedural issues such as guaranteeing both secrecy and transparency at the same time have to be considered. In addition, potential susceptibility to flaws accrues from the multiplicity of agents (computers, servers, networks) involved in the voting procedure, an aspect that can seriously influence the legitimacy of voting. Opponents claim that it is principally impossible to achieve this legitimacy with e-voting. McGaley and McCarthy (2004: 153) state, for example, that "the nature of computers is that their inner workings are secret. Since transactions and calculations happen at an electronic level, it is not physically possible for humans to observe exactly what a computer is doing". In 2015 Richard Hill reported his experience of an attempt to challenge the Geneva e-voting system in court. He filed court challenges against the use of Internet voting in 2011, when e-voting was offered to all voters in Geneva. He wanted the courts to examine if e-voting was consistent with the cantonal law and the Federal Constitution (Hill 2015). According to the Federal Tribunal it is not sufficient to merely claim a weakness of a system and that "an appeal can only be lodged if weaknesses have been actually exploited during a specific vote" (Hill 2015). Regarding vulnerability tests of voting systems, in a recent case in the USA, in Washington, DC, a unique approach was followed: a mock trial was held prior to an Internet election in order to offer everyone who is interested the chance to test the voting system in place (Wolchok et al. 2012). In fact, a research group from the University of Michigan, Ann Arbor, gained control of the election server, changed votes and revealed secret ballots. Their intrusion was not detected by the officials for nearly two business days. According to the "attackers", this case illustrates the practical challenges of securing online voting today (Wolchok et al. 2012). Another incident in connection with Internet voting in Australia was reported by Buell (2015), referring to a standard security flaw detected in a vendor software used for statewide elections. During elections in 2011 in Estonia, despite the fact that election fraud has never been detected, this possibility was much discussed after the parliamentary elections, when an Estonian student claimed that it would be easy to hack and manipulate the Estonian Internet voting system (Rikken 2011). His claim for nullification of the election results was rejected, with the argument that the sole possibility that a computer may have been affected without the voter's knowledge is not reason enough (Sivonen 2011). As a consequence, shortly before the European elections in 2014, a debate about security issues of the Estonian system came up again (Arthur 2014).

Regarding Estonia in particular, the OSCE that accompanied the elections in 2011 recommends some changes and sees room for further improvement of the Internet voting system (OSCE/ODIHR 2011). In 2007, a denial of service attack created problems for many Estonian websites (Jones and Simons 2012), exposing potential vulnerabilities. Evaluators of the security of the system in the 2013 Internet election in Estonia even recommend discontinuing Internet voting in Estonia, concluding "that a state-level attacker, sophisticated criminal, or dishonest insider 
could defeat both the technological and procedural controls in order to manipulate election outcomes" (Springall et al. 2014).

Similar challenges come up in various countries where Internet voting is in place on a regular basis: critics of Internet voting point to vulnerabilities of a system in place, sometimes even filing court challenges. However, their voices remain unheard, seeing as legally nothing can be done as long as a misuse cannot be proved. On the one hand, the sole possibility of fraud is not reason enough to take action; on the other hand, demonstrating flaws would mean committing a crime. Nevertheless, the possibility of indirect effects, such as revisions of e-voting systems due to court challenges or media and public attention, does exist (see also Hill 2015).

There are also several technical issues of practical implementation which remain to be resolved (Beroggi 2014; OSCE/ODIHR 2012, 2013) such as problems during the preparation, vote counting, login and connection as well as the vote casting phases during the test of the Internet voting system in the Canton of Zurich in 2004.

\subsubsection{Socio-political Issues}

Internet voting has the potential to increase voter turnout-this is one central argument brought forward by Internet voting proponents since the beginning of debates about Internet voting. Due to methodological issues, it is rather difficult to make profound claims about the relation between Internet voting and turnout. There is no inevitable causal relationship between the number of participating voters and online voting. Variables such as the immediacy of the issues, positions at stake or people to be elected must also be considered when looking at voter turnout. It is, however, possible to make some assumptions based on a variety of studies dealing with this relation. Reports of the impacts of e-voting initiatives on voter turnout are in fact rather sobering, with results indicating that the move from paper to Internet does not lead to the anticipated increase in total voter turnout. In Norway, for instance, an election evaluation revealed that the turnout levels in the trial municipalities slightly increased, but these are replicated in the whole country (MLGRD 2012). When examining survey data, individuals (primarily young, male, of higher income and education and engaging in frequent social media use) indicate that e-voting would mobilise them in situations where they would otherwise not participate (Spada et al. 2016) and that their interest in e-voting options is high (Carter and Campbell 2011). These survey results are, however, not reflected in data of actual e-voting experiments (Beroggi 2014; MLGRD 2012).

In 2004, a pilot programme for testing an Internet voting system was introduced in the Canton of Zurich, Switzerland, preceded by a survey on the expected benefits of e-voting, providing a very good example of how survey data and expectations on this issue can conflict strongly with findings (Beroggi 2014). Individuals indicated high interest in e-voting as opposed to traditional methods, while the findings showed predominant usage of postal voting. Overall, e-voting did not mobilise more young voters, as the overall age distribution stayed the same, but Beroggi (2014) notes that the average age of e-voters is lower than postal and ballot voters. In 
Norway young voters were optimistic concerning online-voting, but emphasised the symbolic and ceremonial importance of walking to the polling station to submit their vote manually (MLGRD 2012). Based on an analysis of Estonia's Internet elections, Sál (2015) concludes that "the sought correlating relation between internet voting and the total voter turnout can't be convincingly proven".

Investigators of the 2011 election in Estonia explain the influence of e-voting on voter turnout as follows: they distinguish between usage and impact of e-voting and claim that "usage of e-voting is mostly restricted to the politically engaged, but the impact of the technology on the propensity to turn out is highest among 'peripheral' citizens" (Vassil and Weber 2011: 16). The term "peripheral citizens" describes rather disaffected and disengaged individuals, but those few who turn to the Internet option are fascinated by the e-voting application itself.

\subsubsection{Socio-cultural Issues}

Another dimension of e-voting that is discussed regularly deals with the issue of trust in technology and how it might influence election turnout and election outcomes. In order to engage in e-voting, one must have a reasonable amount of trust in the process, which appears to be present in Estonian and Swiss voters and Norwegian election stakeholders, according to the OSCE/ODIHR Election Assessment Mission Reports for the respective countries of 2011, 2012 and 2013. For Estonia, a steady increase of voters choosing to cast their ballot via the Internet from 2005 onwards can be noted (OSCE/ODIHR 2011). Looking at a comparatively high number of Internet elections, it seems that Estonians have gradually built up trust in the system. Concerning Internet voting in Estonia, Vinkel (2012) states that "[...] the factor of trust has been of the upmost importance. Without a doubt, trust will stay the most important factor of choosing internet voting also in the future and building and stabilising this trust is the most important but also one of the most difficult tasks of the election administration". In Norway in 2011 and 2013, the so-called Decryption and Counting Ceremony at election day had the aim to sustain trust in Internet voting by making the decryption and counting of electronic votes public (Markussen et al. 2014). To what extent the ceremony reached its aim remains open. Although the ceremony as such attests to the idea that IT is a socio-technical learning process, making specialised cryptographic elements of Internet voting comprehensible for anyone else than technical experts remains a challenge.

In sum, it is rather obvious that even after more than a decade of conducting and experimenting with Internet voting in various country-specific contexts, several challenges exist. In fact, their relevance is regularly emphasised when online elections in a variety of countries are accompanied by evaluations focussing, for instance, on turnout rates, security aspects, user friendliness or trust. Particularly striking is the large number of critics present in the literature. On a regular basis, system vulnerabilities are made public, sometimes even by filing a lawsuit. All in all, further developments are still needed with regards to technical aspects, legal frameworks, security, transparency and verifiability, as well as oversight and 
accountability. The Swiss trial is lauded by the OSCE/ODIHR (2012) for being good practice, the introduction being careful and limited, ensuring integrity of the systems and building public trust. At first sight, Internet voting might be perceived as an opportunity to alleviate the so-called democratic deficit of the EU. However, as shown empirically, such hopes have not been fulfilled. Essential for voting is not only the convenience aspect, but rather political reasons such as political interest or satisfaction with the political system. And regarding these challenges, Internet voting cannot be a technological quick fix.

\subsection{Experiences with e-Participation at EU-Level}

Over the past two decades, the EU has experienced a "participatory turn" (Saurugger 2010; see also Chap. 3) of its governance regime. Participatory democracy was implemented as a norm in the EU political system and a series of democratic innovations in practice were introduced to strengthen the connections with European citizens and civil society. Meanwhile, there are several contributions to an evaluation of the EU institutions' e-participation activities, such as the volume titled "Is Europe Listening to Us?" (Kies and Nanz 2013) or Lironi's (2016) study for the European Parliament. Based on these and a number of other sources, the following sections will review assessments of major e-participation instruments in use at EU level.

\subsubsection{Deliberative Citizens' Involvement Projects (DCIPs)}

Yang (2013) analysed a variety of 23 "transnational deliberative citizens' involvement projects" between 2001 and 2010 which were sponsored by EU programmes. They are described as a unique case of experimentation, but not as a paradigm shift in European communication policy, seeing as most projects were of a temporary and preliminary nature. Smith (2013) undertook a comparative analysis of design choices and democratic qualities on a subset of these cases, plus one additional case ("European Citizens Consultation-ECC09", "EuroPolis", "Agora", "IdealEU", "Your Voice in Europe-YViEu", plus "Futurum"), pointing out at least three novel challenges involved: large scale, language diversity and transnationality. Three different participation designs, including "deliberative polling" (randomly selected mini publics), "Twenty-first Century Town Meetings" (ICT-supported large-scale one-day events) and "online discussion forums", revealed the following results (Smith 2013: $202 \mathrm{ff}$.):

1. Inclusiveness. The two online examples "YViEu" and "Futurum" showed uneven participation, which damaged their legitimacy as perceived by policymakers. The solution to cope with large scales was open access to online participation and 
randomised or targeted selection for face-to-face participation. An established pattern of EU-level participation is a focus on civil society organisations (CSOs). "YViEu" and "Agora" represent rare examples of institutionalised participation; however, both favour CSOs rather than individual citizens. People with English language skills had an advantage despite considerable efforts to allow for multior trans-lingual engagement.

2. Considered judgement. Opportunities for reasoned interactions and reflections on the judgements of fellow-participants were mixed. Interaction and deliberative quality of "YViEu" and "Agora" were seen as negligible, whereas "ECC09" and "Ideal-EU" allowed for some deliberation, mainly within national communities. "EuroPolis" and "Futurum" even achieved some trans-national exchange; however, none of these designs allowed for the trans-national development of recommendations.

3. Publicity. This aspect was assessed rather sceptically. The observed silence of the media is problematic, since publicity of democratic innovations is crucial for democratic legitimacy.

4. Popular control. Perhaps the most striking finding is the lack of any impact of these participation experiments on decision-making processes. Apart from empowering effects on the participants, there is practically no evidence that outputs were made use of in any form. This also holds for "YViEu", "the only consultation procedure that involves lay citizens to be institutionalised and to have a visible impact on decision-making" (Kies and Nanz 2013: 7). Possible reasons are the still experimental character of these democratic innovations, too broad topics, too general outputs and the failure to clarify how outputs should be integrated into the policy process.

Smith (2013: 212 ff.) points out that deliberative designs, particularly at European scale, bear high costs for organisers (and some also for participants), although the level of investments into these democratic experiments was rather small compared to traditional information campaigns on political issues. E-participation designs may allow saving costs and therefore tend to get priority. For example, implementing "YViEu" as an online platform also intended to save costs on an impact analysis. Inclusive and reasoned deliberation still requires substantial resources when carried out online.

Smith's comparative assessment underlines the feasibility of large-scale deliberative engagement at EU level and points out "Futurum" and "EuroPolis" as good practice examples. However, given the lack of commitment amongst decisionmakers to formally tie the participation projects into the institutional policymaking process, he is rather pessimistic as regards a continuation of deliberative and consultative democratic innovations at EU level. In his opinion, a plebiscitary path as represented by the European Citizens' Initiative (ECI) will prevail as yet another tool benefitting organised interests rather than the citizens of Europe.

Kies and Nanz (2013: 9 ff.) largely share this view, and do not see the ECI specifically designed to further pan-European deliberation. Therefore, the two instruments should be seen as complementary as sufficient evidence has been 
accumulated of the deliberative instruments' positive democratic potential. To improve EU citizens' deliberation activities, they propose the following:

1. A combination of online and offline activities (an open online phase carefully connected with a phase of face-to-face consultations) and a topic of specific interest to promote citizens' inclusion.

2. National-level debates, discussions on propositions from other countries plus summarising national outcomes, followed by an optional pan-European debate, to achieve transnational debate.

3. Steps to increase impact on the political process: formal integration of new participatory instruments, input from citizens that is concrete and of real value for decision-makers and focussing on insights from deliberation processes on why certain decisions should be reached, rather than viewing outcomes as prescriptions for decision-makers.

4. Separate responsibilities for implementation and evaluation to increase the credibility and legitimacy of participatory processes.

Gastil (2013) offers a broader framework to assess the impacts of representative EU deliberation and consultation processes comparatively, distinguishing three types of influence: (1) shaping the views of the participants themselves, (2) informing the judgement of the wider public on an issue and (3) various forms of coupling deliberative events with formal decision-making. At the latter level, policy influence is understood to "improve the deliberation that occurs in these bodies" rather than to "direct government bodies to mindlessly affirm or abandon their previous policy judgements" (Gastil 2013: 221). The coupling between deliberation and decisionmaking can comprise influence on bringing an issue on the public agenda, on defining the problem(s) to be addressed, on naming the choices and alternatives, and finally, direct influence on the decisions taken. Comparing five major EU public participation exercises with the aim "to compare the principal intended paths of influence" (Gastil 2013: 222) leads to the following results: "ECC" and "EuroPolis" are mainly confined to an influence on the participants themselves and the wider public; the former was focussed on educative and civic effects in the agenda setting phase, whereas "EuroPolis" is attributed some potential for improving the understanding of decision-making issues. All three other cases are assessed as carrying potential for different degrees of influence on policymakers: The "Agora" 2008 event on climate change is seen as suitable for influencing policymakers in the form of yielding a broader understanding of the problems involved and of policy choices to be considered. Likewise, "Ideal-EU" had potential for advising public officials through framing available choices and could even reach into shaping the views of relevant alternatives. "YViEu" could have the most direct policy impact since the public is explicitly invited to deliberate on draft legislation and can substantially inform decision-making. Gastil also offers a review of participatory and deliberative arrangements practised around the world, suggesting their adaptation and incorporation into the EU governance system (Gastil 2013: $225 \mathrm{ff}$.). 


\subsubsection{E-consultation Instruments}

Until recently, "Your Voice in Europe" and the European Citizens' Consultation were two key EU e-consultation instruments. In a comparative analysis focussing on institutional strategies in offering these tools, key actors mobilised and main effects, Badouard (2010) deplores the failure to develop a single and concerted strategy for EU-level e-participation offerings. The reasons are different political strategies and actors managing these mechanisms within the institutions, entailing a wide variety of projects.

The platform "YViEu" (today instead simply titled "Consultations") has been established in 2001 as the central site for all online consultations carried out by the various Directorates-General (DGs). These e-consultations aim to allow for the widest possible consultation of specific parts of the public on specific subjects and are regulated by general principles and standards (EC 2002). As stated by Badouard (2010: $101 \mathrm{ff}$.$) , the tool serves a three-part strategy: "Your Voice in Europe stages a$ democratization of the EU, regulates the relationship between the Commission and lobbies, and favours a more effective consultation process." Being regarded as both democratic and efficient, the instrument reconciles the often-assumed tension between openness and efficiency.

The European Citizens' Consultations (ECCs), held between 2007 and 2009, have quite a different mission as a communication tool (Badouard 2010: $102 \mathrm{ff}$.). Combining an online with an offline format, the aim was to initiate a pan-European debate leading to a European public opinion on the future of EU Europe. As such, the ECCs experimented with a new political mediation mechanism which allowed for a "transformative" type of participation by sensitising participants of EU policy issues and contributing to developing a European identity, citizenship and public sphere. In contrast, "YViEu" rather represents an "instrumental" form of participation, as it serves to contribute to specific public policies, institutional transparency and openness and is evaluated with regard to its results. While for "YViEu" the benefit for the Commission is in the foreground, the ECC focusses on the benefit for the citizens.

There are also clear differences concerning the actors involved in the two consultation mechanisms (Badouard 2010: $104 \mathrm{ff}$.). "YViEu" addresses the public using a variety of expressions including "public", "stakeholders", "European citizens" and "interested parties". However, there are some important barriers for "ordinary" citizens: many themes require a highly specialised technical expertise and relevant documents are often only available in a few languages, mostly in English. Consequently, civil society organisations represent the largest group amongst the participants, whereas lay citizens play a rather marginal role. An exceptional case was the European Commission's online consultation on European summertime arrangements held in summer 2018. It received the highest number of responses ever in any Commission public consultation (4.6 million responses from all 28 Member States), showing that this instrument can mobilise massive democratic participation. However, critics have called this form of mass procedures 
"unmanageable, unrepresentative and a source of confusion for the public" (Alemanno 2018: 7).

The ECC instrument contrasts with a special focus on 'ordinary' citizens and practising both a deliberative and an aggregative element. However, this has contributed to the highly complex setup of the process, complicated implementation and lowering the incentives for citizens to engage in deliberation (Karlsson 2010). Badouard's analysis finds that Europe-wide mobilisation of activist networks has been intensive and a further obstacle to the participation of individuals, so that "organised citizens' clearly outweighed "ordinary citizens", also in the ECC case. However, this does not preclude positive effects of successful online mobilisation of activist networks across national borders. This contributed to an important goal of the project, producing a European dynamic and transnational public.

As regards the impact on decision-making, the officially assigned role of consultations is to intervene upstream of the legislative process, so that participants rather contribute to preparing decisions than to directly taking part in decision processes. The conception of the "Your Voice in Europe" mechanism suggests a stronger link between consultation results and decisions, although the outcomes are not legally binding. Badouard argues that obligations to provide adequate feedback also create some pressure on the decisions to be taken and the recognition as a policy instrument, together with institutional accountability, brings the Commission to acknowledge the participants as legitimate political actors. Important conditions for the sustainability of these participatory instruments are their official status and a legal framework on their position in the decision-making process.

An analysis of the ECC by Karlsson (2011) shows that political representation has not been increased through the project as hoped. Members of the European parliament (MEPs) as well as participating citizens appeared to have been disappointed. Karlsson finds the design of the ECC project, at least in part, responsible for the failure. It had a lack of clarity over what inputs are desired by the MEPs and which inputs are expected from the citizens. The form of communication between MEPs and citizens, as well as its management must also be considered carefully. Kies et al. (2013) came to similar conclusions, finding there to be no impact of the deliberation results on decision-makers. They view the ECC as "a successful civic instrument but not a convincing policy instrument" (2013: 24), due to participants perceiving positive impacts such as higher confidence in the EU and informational gains, but politicians disregarding the propositions. A general problem with deliberative projects is the so-called "loss of plurality", in which ideas and inputs of citizens are lost during the phase of condensing all the information into a few limited recommendations. While this is inevitable, one must take care not to lose too much information, as was the case for the ECC (Kies et al. 2013).

Albrecht (2012) reviews the e-consultation practice at EU level with a focus on the "YViEu" platform, building on analyses of other scholars (cf. Quittkat and Finke 2008; Quittkat 2011; Tomkova 2009; Hüller 2008). His main points are: Online consultations have become a well-established instrument, regularly used by practically all DGs. This has certainly increased existing participation opportunities and brought more frequent public participation, especially of diverse interest groups, 
resulting in broadening the input into EU policymaking and extending its knowledge base. However, serious flaws include intransparent and sometimes inadequate processing of contributions; a shift of focus on closed question formats; little evidence of mutual learning and lack of impact on policy outputs; lack of feedback to participants on the use of contributions entailing frustration; one-way format of communication and no opportunities to debate contributions; only limited use of technologies (general purpose instead of specific e-participation and web 2.0 tools); and lacking integration of new arenas for debate, e.g. the political blogosphere (Albrecht 2012: 15 ff.).

He suggests three avenues of improvement: (1) deliberation to enhance input quality, (2) technological advancement and (3) moving towards popular spaces of online debate. Insisting on the double meaning of "deliberation" - an activity on an individual and a collective level-Albrecht advocates a model of deliberative e-consultations which not only consists of collecting comments on a policy proposal but also allows for discussions on these amongst the participants and with representatives of the EU institutions concerned. However, a number of unresolved problems hinder its implementation: to adapt small group and face-to-face formats to a largescale setting, high costs, a minority of participants being willing to engage deeper, the need to facilitate the process and to inform and support the participants, and the reluctance of officials and policymakers to participate. As regards improving technological support, natural language processing and argument visualisation technologies are regarded as interesting candidates, although evaluation results to date are mixed. A third approach suggested is to integrate e-consultations in new ways with social media platforms such as the blogosphere and popular social networking sites, in order to counter the dominating top-down flavour of existing EU channels. The assumption is that a good deal of exchange on these sites includes political talk and that the separation between political content and living realities is being blurred more and more. Several EU projects have already experimented with linking e-consultations to social media (cf. Albrecht 2012: 19). Taken together the three strategies outlined show some promise to develop e-consultations further to a model which is more open and effective than the existing practice and which will also enhance the quality and legitimacy of policy decisions.

To exploit this potential, Albrecht suggests viewing e-consultations mainly as a knowledge management process and to focus on the views considered, rather than focussing on the participatory aspect and who participates. This would include attributing higher value to deliberated opinions than to opinions which are provided without interactive assessment and to integrate social media, not merely as an additional outlet or to inject political messages, but to analyse online discourse and controversies as part of the public opinion with the purpose to inform the formulation of policies. This would mean a turn from "passive listening" in the form of taking up contributions from citizens to "active listening" to civic discourse. Of course, this raises the issue of privacy protection, which has to be guaranteed in such practice. At the same time, in specific cases of e-consultation anonymity might lead to biased results, so that strategies must be developed to reconcile the need for 
identification and negative effects of a forced use of real names (cf. Ruesch and Märker 2012).

A summarised SWOT analysis of online EU public consultations is offered by Lironi (2016):

Specific strengths of EU e-consultations lie in reducing participation thresholds, encouraging participation and active citizenship, increasing democratic legitimacy of EU decision-making, enhancing the quality and transparency of EU rules and decisions, providing a cost-effective way of participation in decision-making, influencing the political process in addition to elections and political parties, reducing the democratic deficit, educating citizens about the EU decision-making and increasing its accountability.

The list of weaknesses is longer (Lironi 2016: $52 \mathrm{ff}$.): EU public e-consultations have low publicity, lack publication of clear feedback and results, are rarely representative for EU citizens and are not user-friendly; the platform "YViEu" is unattractive, intransparent, not user-friendly and ineffective; EU public e-consultations lack meaningful impact on decision-making, can lead to frustration of citizens and are rarely available in all 24 official EU languages; tool design lacks the specific expertise of consultation practitioners; assessments are difficult since evaluation criteria and key performance indicators are lacking; participants often lack the skills for effective participation; the instrument fails to empower individual citizens vis-à-vis organised interest groups; personal opinions rather than informed arguments predominate the contributions; and Commission DGs suffer from additional administrative burdens and diversion of resources.

Nonetheless, opportunities of EU e-consultation instruments include working on the perceived democratic deficit in the EU, the rise of alternative forms of engagement and (young) people's disengagement in "traditional" politics, progress towards more representative consultations with advances in representative statistical sampling methodology, lack of grassroots support for European policy, weak notions of "European Citizenship" and European demos, and technological advancements in ICTs.

Threats include the digital divide between countries (digital infrastructure and e-participation experience), lack of interest in EU politics, the perceived democratic deficit in the EU, and openness to e-participation offerings paired with resistance to fundamental change of decision-making structures.

Recommendations to improve online EU public consultations comprise:

- Upholding the use of this type of e-participation instrument and promoting it

- Making EU e-consultations better known, accessible to citizens and less technical, and always publishing the results with meaningful feedback, on time and with accurate analysis results

- Promoting EU e-consultations as an alternative engagement opportunity to attract those tired of "traditional" forms of politics and to stimulate grassroots discussions and engagement in EU affairs

- Considering a transformation from open consultations to a representative sample model 
- Making sure that no citizen is excluded due to the digital divide and offering complementary offline options for citizens' participation in policymaking

- Efforts to enhance citizens' interest in EU politics and to facilitate their engagement

\subsubsection{The European Citizens' Initiative (ECI)}

The European Citizens' Initiative (ECI), which formally entered into effect on April 1st, 2012, is perhaps the first transnational instrument of participatory democracy worldwide. The ECI gives European citizens an opportunity to influence the legislative initiation process by submitting a proposal to the European Commission. It is now one of the main options amongst the formally institutionalised systems at EU level that provide for connecting bottom-up and top-down forms of participation with the support of digital tools. Principal requirements for the launch of an ECI are that the organisers constitute a citizens' committee with at least seven citizens from at least seven Member States, register the initiative on the ECI website, and collect at least one million support statements from citizens of at least seven of the Member States.

The ECI can be seen as an agenda-setting and policy-shaping instrument which produced great expectations but also scepticism amongst diverse observers, actors and stakeholders regarding the advancement of participatory democracy (cf. Pichler and Kaufmann 2012). Implemented to empower citizens, the ECI is now portrayed as a successful example of civil society mobilisation, seeing as civil society organisations (CSOs) have often been promoters of ECIs (Bouza García 2012: 338 ff.; see also Organ 2014). Bouza García identifies two important potentials: Firstly, the ECI may attract groups that are not highly institutionalised in Brussels, since CSOs that have been strongly active at the EU level may prefer a civil society dialogue. This could empower organisations that have been less able to attract the attention of EU institutions but are able to mobilise citizens, and thus more successful with ECIs. Secondly, with the emergence of new actors and issues, relations between EU institutions and civil society may change from "consensus-prone" to increased contention.

Empirical findings from an analysis of the first 16 initiatives suggest that the ECI has a special potential to enable citizens of small Member States to participate in the EU (Conrad 2013: 301), but the sample is yet too small to draw definitive conclusions. Hrbek (2012: 383) points to the fact, that despite political parties not yet having been organisers of an ECI, they may see potential in this instrument in the future and play a more active role. Whether the ECI will have the potential to realise a better integration of top-down and bottom-up approaches, given the existing social asymmetry amongst the promoters, remains yet uncertain. 


\subsubsection{Criticism}

The procedural demands of the ECI require organisers to deploy extremely high levels of organisational capacities. Digital tools, in particular the Internet's advantage in mobilising support for an initiative, therefore play an important role. Duinkerken (2013: 30) even contends that collecting one million signatures without using modern ICTs would be almost impossible to achieve. However, the online collection software provided by the European Commission has in the past been subject of criticism, including shortcomings regarding its usability (Głogowski and Maurer 2013; Berg and Głogowski 2014; Starskaya and Çagdas 2012). Rustema (2014: 104) proposes that "a true open-source, community-developed" system would better meet the existing challenges. However, since its first release in December 2011, a number of updates have been made to improve the Online Collection Software provided by the European Commission.

\subsubsection{Digital Support}

In addition to reducing campaign costs organisers expect at least three advantages from using the Internet in an ECI process: spreading information about their campaign, disseminating arguments in support of it, and collecting sufficient signatures (Carrara 2012: 358). Sangsari (2013) also sees potential to facilitate the development of an ECI through prior deliberation in online forums as meeting places of organisers with like-minded people.

Typically, each ECI has a dedicated website serving to provide information on the initiative and facilitating online signature collection. Głogowski and Maurer (2013: 18) point out that ECIs "with transparent and user-friendly web pages translated into the majority of European languages have better chances to successfully collect signatures online" — a seemingly simple requirement, but not easy to implement. Carrara also points to the many facets of language barriers, e.g. due to cost reasons; most initiatives before 2012 refrained from opening multilingual online forums that could foster a debate. This poses another challenge to ECI organisers: in contrast to face-to-face collection, it is very resource-intensive to construct a deliberative space that allows for interaction, in many cases an insurmountable task. Therefore, the online presence needs to exhibit the campaign's central statement very clearly, and contain "a strong, intelligible and universal argument register" (Carrara 2012: 360). Meanwhile information on ECIs is distributed via social media which feeds into transnational discourse spaces, but particularly used by young (educated) elites (Knaut 2013; Greenwood 2012). While it is generally believed that the Internet allows for the inclusion of a variety of actors that would otherwise not be prone to public participation (Carrara 2012), Internet literacy is an indispensable prerequisite and Internet availability a decisive factor. Appropriate online channels are indispensable for an efficient transnational participation process; two thirds of the registered initiatives (up to March 2015) have collected statements of support online 
(EC 2015: 9), in the case of the "Right2Water" initiative online collection even accounted for $80 \%$ (EC 2015: 7).

While the online collection of signatures can save time and resources, organisers cannot rely on digital support declarations alone for an initiative to be successful. In contrast to digital collection systems, face-to-face collection is more likely to strengthen citizens' identification with the initiative (Głogowski and Maurer 2013: 18). The role of online collection varies between the Member States, possibly due to differences in current e-participation cultures and levels of Internet access reasons (Carrara 2012: 366). Thomson (2014: 74) observes that campaigns are generally negatively affected by high data requirements, referring to the large amount of personal data, e.g. ID card numbers, signatories have to submit when stating their support for an initiative.

\subsubsection{Points for Improvement}

The current implementation of the concrete terms and rules of the ECI indeed demands significant improvements and modifications in design. Suggestions for major improvement of the online collection software and the entire process have been made (Kaufmann 2012: 240) and recognised to some extent. Additionally, calls were made to extend the period of signature collection to 18 months, to set up an independent helpdesk and to increase access to the signing of an ECI. There are also proposals on multilingual training tools, the clarification of EU data protection law and uniform requirements for signature collection in all Member States (Karatzia 2013). Berg and Thomson (2014: 122) advocate for the following 12 goals:

- "Reduce and harmonise personal data requirements across Member States;

- eliminate ID number requirements;

- ensure that all EU citizens can support an ECI-wherever they live;

- lower the age of ECI support to 16;

- redesign the online signature collection system;

- collect the e-mail address within the main ECI support form;

- lengthen the signature collection time to 18 months;

- give ECI campaigns time to prepare: let them choose their launch date;

- provide a support infrastructure for ECIs with legal advice, translation and funding;

- provide an EU legal status for ECI citizens' committees;

- remove or modify the first legal admissibility check;

- increase public and media awareness of the ECI."

Lironi (2016: 51) similarly argues for an intensified promotion of the ECI as a tool, increasing the user-friendliness of the ECI (e.g. through a reduction and harmonisation of identification and data requirements), and altering the signature collection timeframe.

A study commissioned by the European Parliament (Ballesteros et al. 2014) identified obstacles for the ECI in six areas covering the entire ECI process: 
registration, certification of the online collection system, signature collection, verification and submission of statements and horizontal issues such as data protection or funding transparency. Here, measures to create a one-stop-shop for supporting ECI organisers as well as improving the signature collection software and support forms are seen as essential. The study concludes with recommendations to increase the ECI's effectivity, with concrete suggestions for revising both Regulation 211/2011 as well as EU primary law, the TEU (EP 2014). Key points include amending the TEU to either revising the ECI as an agenda-setting tool-in this case the Commission would not be obliged to follow a successful initiative with legislation-or revising the ECI as a tool for legislative initiative, meaning that citizens could have real legislative power within a certain framework. More specifically the study suggests a two-step system where, for instance, half a million signatures would request the $\mathrm{EC}$ to propose legislation, whereas one million signatures would oblige the EC to do so. The demand for introducing obligatory actions is strongly contested, as a million signatures cannot be considered representative for EU citizens.

The ECI as an institutional innovation for enhancing not only the citizens' influence on EU-level decision-making but also for contributing to the formation of a European public sphere has at best been of modest success to date. It would, however, be too pessimistic to conclude that the instrument has a predominantly symbolic function. It is to some extent still an experiment with many open questions and it was therefore wise to include a clause for a possible revision every 3 years after a period of gathering experience with the new instrument. For now, it seems that the ECI's relevance is far greater on the discursive level than in terms of the concrete policy-shaping impact.

The European Citizens' Initiative (ECI) was envisioned to increase direct participation in EU law-making, but seems to have failed in conveying its message to citizens as there appears to be no connection between knowing about the ECI and the image of the EU or being willing to use the tool (Gherghina and Groh 2016). Monaghan (2012) speculates that perhaps the output-based approach and the measurement of the ECI in Commission Green Papers or Proposals is not relevant to EU citizens, as they are more interested in changes in their political realities. The potentials of the ECI appear to remain untapped, which is unfortunate as Lironi (2016) refers to possible benefits such as strengthened participation of citizens in policymaking and consequently increased political legitimacy.

Most recent developments show some remarkable progress as regards the use and role of this instrument which underlines its democratic potential. After the conclusion of our study, the European Commission presented a legislative proposal to revise the European Citizen' Initiative, which entails several changes primarily addressing the liability of initiative organisers, the provision of information and advice, the registration phase of initiatives, the minimum age to support initiatives, the signature collection phase and the review provisions (EC 2017). Whether the interpretation of these developments as "impressive signs of previously unseen institutional matureness and political energy" (people2power 2017) of the ECI will be sustained remains to be seen. 


\subsubsection{E-Petitions of the European Parliament}

The option to submit a petition to the European Parliament via the Internet is another form of using digital tools within a participatory instrument at EU level. The Committee on Petitions (PETI) is the body that is responsible for treating petitions and deciding on which kind of action to take.

According to a recent report (PETI 2015), citizens mainly petitioned about the environment, fundamental rights, justice, the internal market and European policy development and used the tool in order to contest or argue against decisions and rulings which were made. In 2014, 2714 petitions received marked a slight decrease from the previous year, the trend in the past few years having been rising. More than half $(59.6 \%)$ of these petitions were closed at early stages due to three main reasons: the petition was deemed inadmissible, was closed after information on the relevant subject was communicated to the petitioner, or was closed due to being addressed to the wrong EP committee. A total of 1168 petitions were admissible, of which 1119 were passed on to the Commission for an opinion. English, German, Spanish and Italian are the languages most commonly used within the petitions (collectively accounting for $72 \%$ ). While Germans, Spaniards and Italians were the most active petitioners, citizens from Estonia and Luxembourg were strongly underrepresented (PETI 2015).

Back in 2009, 63.2\% of all petitions were sent via e-mail; this percentage has increased to $80 \%$ in 2014 (PETI 2015), the Internet being the preferred method for petitioning. In 2014, the PETI report documents $80 \%$ of the admitted petitions being closed within a year. An important observation made annually in these PETI reports is the fact that citizens "[...] confuse the EU institutions and those of the Council of Europe, in particular the European Court of Human Rights" (PETI 2015: 24). In November 2014 a new Petitions web portal was introduced, possessing more feedback features on the status of petitions and more information on the Parliament's areas of competence. The PETI report welcomes this development, though it points out that in order to reach the petitions page, a user must navigate through four pages from the Europarl homepage. Another criticism was the length of the whole petition process, particularly the long time needed by the PETI Committee to verify petitions (Lironi 2016: 37).

Tiburcio (2015) examined "The Right to Petition" to the European Parliament for the Committee on Petitions, noting that recent studies on petitions tend to neglect it, although it represented a "well-embedded process to deal with petitions" (Tiburcio 2015: 12). He comes to the following conclusion: "[...] the petition system of the European Parliament compares well overall with the petition systems of Parliaments of Member States. In terms of conventional features, it scores well in all dimensions: it ensures direct access (and not intermediate) by citizens; it is highly inclusive and open to both national citizens of Member States as nationals from third countries, if they reside within the EU territory; it offers possibilities for greater involvement of citizens, including through frequent holding of hearings, followed by public debate in committee" (Tiburcio 2015: 40). 
He does, however, identify several weaknesses which have yet to be resolved, such as an information gap, and recommends working on the following points:

- Clearer information

- Publication of more detailed information related to the petition process

- Publication of all documents related to the petition

- A better and more focussed communication strategy

- Getting to know who the petitioners are (sex, age, education, occupation, etc.)

- Learning opinions and experiences of petitioners

- Conducting a public survey on citizen knowledge of the right to petition the European Parliament

- Investing in EU promotional material

- Collection of statistical data on the treatment of petitions on the PETI web portal.

\subsubsection{Summary}

The democratic innovations introduced in the course of the EU's "participatory turn" represent a variety of participatory instruments, practically all of which make use of digital tools in one form or another. They embody types of e-participation mainly contributing to political agenda setting or to be considered in decision-making (e-deliberative designs, e-consultations, e-initiatives or e-petitions). Similar instruments are also practised at national and sub-national levels; however, the supranational nature of the EU poses three novel challenges: large scale, language diversity and trans-nationality.

As was shown, the experiences from over a decade of experimentation with various participatory designs, as well as in part regular use at EU level, have been mixed. The democratic potential of the existing participatory instruments, in particular the support of digital tools to enhance direct and participatory democracy, has been proved in many respects to different degrees. However, a number of serious challenges, unsolved problems and unfulfilled expectations have also been encountered.

Assessments of various types of deliberative participatory designs reveal many starting points to improve the democratic quality. The lack of any impact on decision-making is one of the most striking findings. The often experimental character is not the only reason; at times too broad topics, too general outputs and the lack of clear rules on how to integrate outputs into the policy process seem to be the biggest barriers. Opportunities for deliberation allowing for considered judgement are rare and usually limited to national communities. The "Europolis" and "Futurum" designs represented positive exceptions and demonstrated the possibility of trans-national exchange. The focus on civil society organisations rather than ordinary citizens, and the fact that this is a frequent pattern, challenges the ideal of inclusiveness. The lack of publicity of these democratic innovations, the silence of 
the media on them and the difficulties to mobilise citizens for participation are special points of grievance.

A more differentiated view of the issue of policy impact acknowledges several types of influence: on the participants themselves, the wider public and formal decision-making. Rather than being understood as a one to one translation of suggestions into policy decisions, the latter type of impact can mean improved deliberation in governmental bodies and more indirect impact by shaping the preparation of decisions along the various phases from agenda setting and problem analysis to framing choices and finally taking decisions. Likely impacts also depend on institutional strategies in offering particular participatory designs, for example, whether conceived as a policy instrument, such as e-consultations via the "Consultations" platform, or a communication instrument with a transformative mission aimed at sensitising participants of EU policy issues, such as the ECCs. Though e-consultations have become a well-established instrument in practically all DGs which has certainly broadened the input into EU policymaking and extended its knowledge base, serious flaws need to be worked on, such as intransparent processing, lack of feedback and lack of impact on policy outputs.

Finally, experiences with the ECI have shown that for the time being the potential to act as an effective bridge between bottom-up claims to participate in EU policymaking and formal institutions has not been realised as expected. Much acclaimed as the first formally institutionalised transnational instrument of participatory democracy, it has been more a tool for civil society mobilisation than citizen empowerment up to this point, since it requires enormous organisational capacities on the part of organisers of an ECI. However, most recently the signs of improved performance and increased use of this instrument look more promising. Digital support is indispensable and plays an even stronger role in most recent initiatives; still, it is all the more necessary to cure remaining deficits in support by the existing online collection system and other barriers identified. The European Parliament's e-petition system also requires some improvement by facilitating access and speeding up the whole petition procedure in order to raise its value as an instrument of participatory democracy.

\subsection{Conclusions}

\subsubsection{Experience with Digital Tools in Different Types of e-Participation}

The assessment of the European Citizen Consultations by Kies et al. (2013: 24) as "a successful civic instrument but not a convincing policy instrument" appears applicable for a great many e-participatory tools within various e-democracy sectors. It seems to be an ongoing theme that e-participatory projects provide added personal value for participants and community capacity, but suffer from a lack of direct, or 
even indirect, political impact. "There exist more opportunities than ever before for citizens wishing to have their say, via the media or directly to local and national governments, but there is a more pervasive sense of disappointment than ever before that citizens are outside the citadels of power, and that those within do not know how to listen to them" (Coleman and Moss 2012: 4).

A differentiated offer of e-consultations has been developing over the years at all government levels in a variety of formats (from simple questionnaires to open formats and crowdsourcing). However, it appears that at times a project which at first glance appears to be participatory will turn out to not have consultative or deliberative character, but have the objective to inform citizens about decisions already having been made. In the cases where citizen input is in fact the objective, there can be great uncertainty on what sorts of inputs are desired and how to produce them best. Designs of e-consultation processes need to cope with a tension between the goals of quality of inputs and inclusivity. Often the issues at stake require highly specialised expertise which average citizens do not possess but which are only available from civil society organisations. Well-designed e-consultation processes with transparent processing and appreciation of inputs contribute to heightened legitimacy of policy agendas. E-consultation processes are of low value when topics are too broad, the outputs too general and the rules or formal steps on how to integrate outputs into the policy process are lacking.

In the area of e-petitions successful examples of modernisation with the introduction of e-petition systems are observable. The increasing share of online petitions underlines high public acceptance but does not necessarily boost the overall amount of petition activity. Internet use does not automatically increase transparency and enhance opportunities for participation. There are indications that such effects require the cooperation of institutional and organisational reform and technological modernisation. A certain level of civic knowledge or skills on part of the petitioners was also stressed to be needed in order for petitions to be successful.

On concrete topics of life world relevance, e-deliberation systems enjoy high citizen interest and can be a cost-effective tool of engagement. A special advantage of e-deliberation can be that anonymity allows an exchange of ideas without regarding hierarchical factors such as social status. However, in order to cultivate successful deliberation and to ensure quality and a level of respect within the online discourse a moderation system and structure is important. A balance must be struck between structuring e-participatory events, such as adding moderators which can have positive effects on the quality and therefore the impact of the deliberation, and the aspect of inclusivity, which appears incompatible with high expertise levels and complexity. It is obvious that the success of deliberative e-participation events depends on the deliberative skills of the participants. These are not equally distributed in society and require training. New formats of large-scale citizen deliberation (combining offline and online formats) such as so-called citizen forums in Germany can have stimulating effects on a wider scale as regards civic discourse and awareness of public issues of relevance.

The area of $e$-budgeting may, at this point in time, have produced some of the strongest results when it comes to influencing decision-making, despite not 
necessarily leading to changed power relations between governments and citizens. Amongst the impacts identified are the following: support to demands for increased transparency, improved public services, accelerated administrative operations, better cooperation amongst public administration units and enhanced responsiveness. Positive contributions to the political culture and competences of participants can also be expected (e.g. extended participation opportunities, better quality of decision-making, increased legitimacy and a stronger identification with the local community). Cost reduction and major structural reforms are less likely.

As regards $e$-voting, even after more than a decade of experiences with trials and real use of Internet voting, several challenges exist and those elaborated in Lindner et al. (2016) have not lost any topicality, especially regarding the issues of turnout rates, security, user friendliness or trust. The literature contains a large number of critics addressing system vulnerabilities. They emphasise the need for further advances regarding technical design, legal regulation, security, transparency and verifiability as well as oversight and accountability. The reported Swiss trial can serve as a good practice example. However, hopes that Internet voting might cure the democratic deficit of the EU have not been met. Technology alone cannot address deeper causes for dissatisfaction and continuously falling voter turnout in EU elections.

An area to which much attention has been paid during the last years is social media. They have certainly become an important channel for political communication and targeted political propaganda. Opinions seem to differ greatly regarding the impact social media use (such as Facebook and Twitter) has on online and offline participation. Results range from Facebook use leading to decreased participation in all areas to online participation, and even offline protests, being promoted by the same site. In general, it does appear, however, that there is a tendency for mobilisation to be medium-specific. While political websites tend to still mainly serve an informative purpose, more and more politicians become accessible through the use of social media platforms such as Twitter, allowing for a dialogue between elected officials and citizens. An interesting phenomenon which adds to the difficulty of mobilisation is the fact, that being confronted with political opinions which differ from your own can lower political interest and engagement. Political deliberation and discussions on social media sites can therefore have negative effects on a person's willingness to engage in similar dialogues in the future. One must of course also not forget the various technical and privacy problems associated with e-democracy, as well as the fact that many countries still possess a significant digital divide.

A general problem that applies to all e-participatory procedures and tools is to strike a balance between quality or security enhancing design features and the aspect of inclusivity, which appears incompatible with high levels of complexity and expertise requirements. Currently amongst those making use of e-voting, e-deliberation and e-petitioning offers, there is an overrepresentation of young white males with a high educational background, whereby these individuals tend to migrate from offline voting, deliberation and petitioning to online versions without an increase of overall participation being achieved. "... [A] vast amount of research shows that the 
costs and benefits of participation are generally skewed in favor of those with higher socio-economic status (SES) and education levels. While other factors, such as membership in civic and political organisations and various social networks, can mitigate the impacts of SES and education, it is clear that unless practitioners take corrective measures, participation of all varieties will be skewed" (Ryfe and Stalsburg 2012: 1).

Naturally this problem has led to several mobilisation attempts, since a lack of diversity and representativeness of participatory projects inevitably results in decreasing interest from policy- and decision-makers and therefore in lower impact. Mobilisation has proven to be one of the great challenges of participatory projects in general, one of the explanations being that citizens have low confidence that their input in such projects will have any real weight in decision-making processes. This scepticism appears to be well-founded, judging by the low significance of e-petitions and e-deliberative events for legally binding outcomes, even if heightened legitimacy of policy agendas can be achieved. Deliberative civic engagements tend not to be embedded in political decision-making, often making them short-lived, temporary and focussed on single particular issues, characteristics which may contribute to the scepticism of citizens regarding their significance. Further barriers preventing mobilisation are language problems and low interest in European-level matters. Furthermore, promising projects such as the ECI are aimed at increasing participation on the side of civil society organisations rather than on the individual level. A factor for success which cannot be stressed enough for all of these civic engagement projects is the support and engagement of decision-makers.

\subsubsection{Experiences with e-Participation at EU-Level}

The democratic innovations introduced at supra-national level pose enormous novel challenges to cope with, in particular large scale, language diversity and transnationality. The experience from over a decade of usage and experimentation with innovative participatory designs at EU level has been mixed. The support of digital tools to enhance direct and participatory democracy has been proved in many respects, despite the fact that a number of problems have been encountered and exaggerated expectations of new democratic potentials have not been fulfilled.

A clear finding regarding deliberative participatory designs is their absolute lack of impact on decision-making. Reasons behind are inexistent formal rules for integration into the policy process, often too broad topics or unspecific outputs and sometimes still experimental status. As far as opportunities for deliberation leading to reasoned judgement exist at all, they are largely confined to communities at regional or national levels. "Europolis" and "Futurum" are positive exceptions, demonstrating that trans-national exchange is possible. The ideal of inclusiveness is seriously challenged by the dominance of civil society organisations as compared to giving ordinary citizens a say and the difficulties to mobilise these for 
participation. A special problem is also the disinterest of the media on these democratic innovations.

Taking a more differentiated view on the lack of policy impact of participatory designs reveals different modes and degrees of influence beyond the effects on the participants themselves or the wider public and beyond a one to one translation of input into formal decisions. This can mean improved deliberation in decisionmaking bodies, shaping the preparation of decisions in agenda setting, problem analysis and framing of choices up to the final taking of decisions. Institutional strategies in offering particular participatory designs also make a difference for their impact. The "Your Voice in Europe" platform was conceived as a policy instrument and the ECCs as a communication instrument. E-consultations are now a wellestablished practice across all DGs which certainly broadened the input into EU policymaking, however, serious flaws such as intransparent processing and lack of feedback need to be corrected.

Finally, expectations of the ECI as an effective bridge between bottom-up claims to participate in EU policymaking and formal institutions have not been fulfilled as hoped for. Up to now it is still rather an instrument for civil society mobilisation than citizen empowerment. The organisational capacities required by organisers are enormous. Digital support is indispensable, as are ongoing improvements of the online collection system and other barriers identified. On the side of the European Parliament the e-petition system also deserves higher visibility, efforts in facilitating access and speeding up the whole procedure to become a true instrument of participatory democracy.

What consequences to draw as regards the future of these democratic innovations is of course a political question. From the perspective of participatory democracy the definite recommendation to the EU institutions is to focus on improving the existing e-participation tools at EU level along the lines suggested by the assessments and the results of the SWOT analyses in the relevant literature presented. The institutional singularity of the EU as a supra-national entity prevents a simple transposition of experiences to the EU level. Instead careful selection and adaptation of positive models is required. This would suggest starting initiatives to promote new forms of e-participation and to gather experience through experimentation, for example, with crowdsourcing inspired by successful projects at national level. Another option worth thinking about could be how to strengthen the EU Parliament's representative character by building on MEPs as bridges to citizens with the support of digital platforms for facilitating citizens' participation in EU policymaking. Finally, further experimentation with appropriate new designs to foster deliberative engagements of citizens and, last not least, a further exploration of possibilities to integrate e-participatory designs with external "third places", i.e. social media platforms, seem worthy to be considered. 


\section{References}

Aitamurto, T., \& Landemore, H. (2016). Crowdsourced deliberation: The case of the law on off-road traffic in Finland. Policy and Internet, 8(2), 174-196.

Alathur, S., Ilavarasan, P. V., \& Gupta, M. P. (2012). Citizen participation and effectiveness of e-petition: Sutharyakeralam - India. Transforming Government: People, Process and Policy, 6 (4), 392-403.

Albrecht, S. (2012). E-Consultations: A review of current practice and a proposal for opening up the process. In E. Tambouris, A. Macintosh, \& O. Saebo (Eds.), Electronic participation (pp. 13-24). Berlin: Springer.

Alemanno, A. (2018). Beyond consultations: Reimagining European participatory democracy. Carnegie Europe, reshaping European democracy. Accessed January 23, 2019, from https:// ssrn.com/abstract $=3304510$

Allcott, H., \& Gentzkow, M. (2017). Social media and fake news in the 2016 election. Journal of Economic Perspectives, 31(2), 211-236.

Andersen, K. N., \& Medaglia, R. (2009). The use of Facebook in national election campaigns: Politics as usual? Lecture Notes in Computer Science, 5694, 101-111.

Arthur, C. (2014, May 12). Estonian e-voting shouldn't be used in European elections, say security experts. Accessed February 23, 2019, from https://www.theguardian.com/technology/2014/ may/12/estonian-e-voting-security-warning-european-elections-research

Åström, J., Jonsson, M., \& Karlsson, M. (2016). Democratic innovations: Reinforcing or changing perceptions of trust? International Journal of Public Administration, 1-13.

Badouard, R. (2010). Pathways and obstacles to eParticipation at the European level. A comparative analysis of the European Citizens' Consultation 2009 and the online consultations of the European Commission. JeDEM, 2 (2), 99-110. Accessed January 23, 2019, from http:// jedem.org/index.php/jedem/article/view/30

Baek, Y. M., Wojcieszak, M., \& Carpini, M. X. D. (2012). Online versus face-to-face deliberation: Who? Why? What? With what effects? New Media and Society, 14(3), 363-383.

Ballesteros, M., Canetta, E., \& Zaciu, A. (2014). European citizens' initiative - First lessons of implementation. Study. European Parliament, Directorate General for Internal Policies, Policy Department C: Citizens' Rights and Constitutional Affairs. Brussels: European Parliament. Accessed January 23, 2019, from www.europarl.europa.eu/RegData/etudes/STUD/2014/ 509982/IPOL_STU(2014)509982_EN.pdf

Barber, B. J. (1984). Strong democracy: Participatory politics for a new age. Berkeley, CA: University of California Press.

Baringhorst, S. (2009). Introduction. Political campaigning in changing media cultures - typological and historical approaches. In S. Baringhorst, V. Kneip, \& J. Niesyto (Eds.), Political campaigning on the web (pp. 9-30). Bielefeld: Transcript.

Barrett, G., Wyman, M., \& Schattan, P. C. V. (2012). Assessing the policy impacts of deliberative civic engagement. In T. Nabatchi, J. Gastil, M. Leighninger, \& G. M. Weiksner (Eds.), Democracy in motion: Evaluating the practice and impact of deliberative civic engagement (pp. 181-204). Oxford/New York: Oxford University Press.

Berg, C., \& Głogowski, P. (2014). An overview of the first two years of the European citizens' initiative. In C. Berg, \& J. Thomson (Eds.), An ECI that works! Learning from the first two years of the European Citizens' Initiative. The ECI Campaign (pp. 11-18). Accessed January 22, 2019, from www.ecithatworks.org/wp-content/uploads/2014/04/An_ECI_That_Works.pdf

Berg, C., \& Thomson, J. (2014). Lessons and recommendations for an ECI that works. In C. Berg, \& J. Thomson (Eds.), An ECI that works! Learning from the first two years of the European Citizens' Initiative. The ECI Campaign (pp. 118-122). Accessed January 22, 2019, from http:// www.ecithatworks.org/wpcontent/uploads/2014/04/An_ECI_That_Works.pdf

Beroggi, G. (2014). Internet voting: An empirical evaluation. Computer, 47(4), 44-50.

Beroggi, G., Moser, P., \& Bierer, D. (2011). Evaluation der E-Voting Testphase im Kanton Zürich 2008-2011: Testphase basierend auf RRB 1770/2007. 
Bochel, C. (2013). Petitions systems: Contributing to representative democracy? Parliamentary Affairs, 66(4), 798-815.

Boussaguet, L. (2016). Participatory mechanisms as symbolic policy instruments? Comparative European Politics, 14(1), 107-124.

Bouza García, L. (2012). New rules, new players? The ECI as a source of competition and contention in the European public sphere. Perspectives on European Politics and Society, 13 (3), 337-351.

Bräunlich, K., Grimm, R., Richter, P., \& Roßnagel, A. (2013). Sichere Internetwahlen: Ein rechtswissenschaftlich-informatisches Modell. Baden-Baden: Nomos.

Buell, D. A. (2015). Computer Security and the Risks of Online Voting. Communications of the ACM, 58(7), 13-14.

Cabannes, Y. (2015). The impact of participatory budgeting on basic services: Municipal practices and evidence from the field. Environment and Urbanization, 27(1), 257-284.

Cardenal, A. S. (2011). Why mobilize support online? The paradox of party behavior online. Party Politics, 19(1), 83-103.

Carrara, S. (2012). Towards e-ECIs? European participation by online pan-European mobilization. Perspectives on European Politics and Society, 13(3), 352-369.

Carter, L., \& Campbell, R. (2011). The impact of trust and relative advantage on internet voting diffusion. Journal of Theoretical and Applied Electronic Commerce Research, 6(3), 28-42.

Chadwick, A. (2011). Explaining the failure of an online citizen engagement initiative: The role of internal institutional variables. Journal of Information Technology and Politics, 8(1), 21-40.

Cho, J., \& Keum, H. (2016). Leveling or tilting the playing field: Social networking sites and offline political communication inequality. Social Science Journal, 53(2), 236-246.

Coleman, S., \& Moss, G. (2012). Under construction: The field of online deliberation research. Journal of Information Technology and Politics, 9(1), 1-15.

Coleman, S., \& Spiller, J. (2003). Exploring new media effects on representative democracy. The Journal of Legislative Studies, 9(3), 1-16.

Collingwood, L., \& Reedy, J. (2012). Listening and responding to criticisms of deliberative civic engagement. In T. Nabatchi, J. Gastil, M. Leighninger, \& G. M. Weiksner (Eds.), Democracy in motion: Evaluating the practice and impact of deliberative civic engagement (pp. 233-259). New York, NY: Oxford University Press.

Conrad, M. (2013). Small-states perspective on the European citizens' initiative. Icelandic Review of Politics and Administration, 9(2), 301-322.

Council of Europe. (2005). Legal, operational and technical standards for e-voting: Recommendation Rec(2004)11 adopted by the Committee of Ministers of the Council of Europe on 30 September 2004 and explanatory memorandum.

Davies, T., \& Chandler, R. (2013). Online deliberation design: Choices, criteria, and evidence. In T. Nabatchi, J. Gastil, M. Leighninger, \& G. M. Weiksner (Eds.), Democracy in motion: Evaluating the practice and impact of deliberative civic engagement (pp. 103-131). New York, NY: Oxford University Press.

Davis, R. (2005). Politics online. Blogs, chatrooms and discussion groups in American democracy. New York, NY: Routledge.

Driza-Maurer, A., Spycher, O., \& Taglioni, G., Weber, A. (2012). E-voting for Swiss Abroad: A joint project between the confederation and the cantons. In M. Kripp, M. Volkamer, \& R. Grimm (Eds.), Electronic Voting 2012. Proceedings of the 5th Conference on Electronic Voting 2012 (EVOTE2012) (pp. 173-187), Bonn.

Duinkerken, M. J. (2013). Die Europäische Bürgerinitiative - Ein effektives Instrument direkter Partizipation? Bachelor thesis. Accessed January 22, 2019, from www.epub.ub.uni-muenchen. de/15085/1/Duinkerken_Final_41.pdf

Dunne, K. (2015). ICTs: Convenient, yet subsidiary tools in changing democracy. International Journal of E-Politics (IJEP), 6(2), 1-13. 
EC - European Commission. (2002). Towards a reinforced culture of consultation and dialogue General principles and minimum standards for consultation of interested parties by the Commission. Communication from the Commission, COM(2002) 704 final Brussels, 11.12.2002.

EC - European Commission. (2015). Report from the Commission to the European Parliament and the Council. Report on the application of Regulation (EU) No 211/2011 on the citizens' initiative. Brussels, 31.3.2015, COM(2015) 145 final. Accessed January 23, 2019, from http:// ec.europa.eu/transparency/regdoc/rep/1/2015/EN/1-2015-145-EN-F1-1.PDF

EC - European Commission. (2016). Compendium of international standards for Elections. Accessed January 23, 2019, from www.eeas.europa.eu/sites/eeas/files/compendium-en-n-pdf. pdf

EC - European Commission. (2017). Proposal for a Regulation of the European Parliament and of the Council on the European Citizens' Initiative. Brussels, 13.9.2017, COM(2017) 482 final. Accessed January 23, 2019, from http://www.europarl.europa.eu/RegData/docs_autres_institu tions/commission_europeenne/com/2017/0482/COM_COM(2017)0482_EN.pdf

Edwards, A., \& de Kool, D. (2016). Digital democracy: Opportunities and dilemmas. The Dutch parliament in a networked society. Den Haag: Rathenau Instituut.

El Noshokaty, A. S., Deng, S., \& Kwak, D. H. (2016). Success factors of online petitions: Evidence from change.org. Paper presented at the Proceedings of the Annual Hawaii International Conference on System Sciences.

EP - European Parliament. (2014). European Citizens' initiative - First lessons of implementation. Directorate General for Internal Policies. Policy Department C: Citizens' Rights and Constitutional Affairs. Petitions and Constitutional Affairs.

Escher, T. (2011). TheyWorkForYou.com. Analysis of users and usage for UK Citizens Online Democracy. Retrieved from http://www.mysociety.org/files/2011/06/TheyWorkForYou_ research_report-2011-Tobias-Escher1.pdf. Accessed January 23, 2019.

Fedotova, O., Teixeira, L., \& Alvelos, H. (2012). E-participation in Portugal: Evaluation of government electronic platforms. In J. Varajao, M. Cunha, P. Yetton, \& R. Rijo (Eds.), 4th Conference of enterprise information systems - Aligning technology, organizations and people (Vol. 5, pp. 152-161).

Font, J., del Amo, S. P., \& Smith, G. (2016). Tracing the impact of proposals from participatory processes: Methodological challenges and substantive lessons. Journal of Public Deliberation, 12(1), Article 3.

Frey, C. B., Berger, T., \& Chen, C. (2018). Political machinery: Did robots swing the 2016 US presidential election? Oxford Review of Economic Policy, 34(3), 418-442.

Garrone, P. (2005). Fundamental and political rights in electronic elections. In A. H. Trechsel \& F. Mendez (Eds.), The European Union and E-voting - Addressing the European Parliament's internet voting challenge (pp. 111-123). New York: Routledge.

Gastil, J. (2013). A comparison of deliberative designs and policy impact in the EU and across the globe, Chapter 9. In R. Kies \& P. Nanz (Eds.), Is Europe listening to us? Success and failure of EU citizen consultations (pp. 217-237). Farnham: Ashgate.

Germann, M., \& Serdült, U. (2014). Internet voting for expatriates: The Swiss case. Journal of eDemocracy, 6(2), 197-215.

Gherghina, S., \& Groh, A. (2016). A poor sales pitch? The European citizens' initiative and attitudes toward the EU in Germany and the UK. European Politics and Society, 17(3), 373-387.

Głogowski, P., \& Maurer, A. (2013). The European citizens' initiative - Chances, constraints and limits, political science series. Vienna, Austria: Institute for Advanced Studies.

Goncalves, S. (2013). The effects of participatory budgeting on municipal expenditures and infant mortality in Brazil. World Development, 53, 94-110.

Gordon, V., Osgood, J. L., \& Boden, D. (2017). The role of citizen participation and the use of social media platforms in the participatory budgeting process. International Journal of Public Administration, 40(1), 65-76. 
Graham, T., Jackson, D., \& Wright, S. (2016). 'We need to get together and make ourselves heard': Everyday online spaces as incubators of political action. Information Communication and Society, 19(10), 1373-1389.

Greenwood, J. (2012). The European citizens' initiative and EU civil society organisations. Perspectives on European Politics and Society, 13(3), 325-336.

Grimmelikhuijsen, S. G., \& Meijer, A. J. (2014). Effects of transparency on the perceived trustworthiness of a government organization: Evidence from an online experiment. Journal of Public Administration Research and Theory, 24(1), 137-157.

Guidetti, M., Cavazza, N., \& Graziani, A. R. (2016). Perceived disagreement and heterogeneity in social networks: Distinct effects on political participation. Journal of Social Psychology, 156(2), 222-242.

Hale, S. A., Margetts, H., \& Yasseri, T. (2013, May). Petition growth and success rates on the UK No. 10 Downing Street website. In Proceedings of the 5th Annual ACM Web Science Conference (pp. 132-138).

Hall, T. (2012). Electronic voting. In N. Kersting (Ed.), Electronic democracy (pp. 153-176). Opladen: Barbara Budrich Publishers.

Heiberg, S., Laud, P., \& Willemson, J. (2012). The application of I-voting for Estonian parliamentary elections of 2011. In A. Kiayias \& H. Lipmaa (Eds.), E-Voting and Identity. Vote ID 2011. Lecture Notes in Computer Science, 7187 (pp. 208-223). Berlin/Heidelberg: Springer.

Heidelberger, C. A. (2009). Electronic participatory budgeting: Supporting community deliberation and decision-making with online tools. Conference Paper Midwest Decision Sciences Institute Conference, Miami University, Oxford, OH, April 16-18.

Hern, A. (2018). The Guardian. Cambridge Analytica: How did it turn clicks into votes? (online). Published 6.05.2018. Accessed January 23, 2019, from https://www.theguardian.com/news/ 2018/may/06/cambridge-analytica-how-turn-clicks-into-votes-christopher-wylie

Hill, R. (2015). Challenging an E-voting system in court: An experience report. In R. Haenni et al. (Eds.), VoteID 2015 (pp. 161-171).

Howard, P. N., Woolley, S., \& Calo, R. (2018). Algorithms, bots, and political communication in the US 2016 election: The challenge of automated political communication for election law and administration. Journal of Information Technology and Politics, 15(2), 81-93.

Hrbek, R. (2012). National and European political parties and the European citizens' initiative. Perspectives on European Politics and Society, 13(3), 370-384.

Hüller, T. (2008). Gut beraten? Die Online-Konsultationen der EU Kommission. Zeitschrift für Politikberatung, 1(3), 359-382.

Im, T., Cho, W., Porumbescu, G., \& Park, J. (2014). Internet, trust in government, and citizen compliance. Journal of Public Administration Research and Theory, 24(3), 741-763.

Jones, D., \& Simons, B. (2012). Broken ballots: Will your vote count? (CSLI lecture notes, Vol. 204). Stanford, CA: CSLI Publications.

Karatzia, A. (2013). The European citizens' initiative: Giving voice to EU citizens. King's student law review. London: King's College. Accessed January 23, 2019, from http://blogs.kcl.ac.uk/ kslreuropeanlawblog/?p=452\#.VIbxlsnm59M

Karlsen, R. (2011). Still broadcasting the campaign. On the Internet and the fragmentation of political communication with evidence from Norwegian electoral politics. Journal of Information Technology and Politics, 8(2), 146-162.

Karlsson, M. (2010). A panacea for Pan-European citizen participation? Analysis of the 2009 European citizen consultations. In E. Amna (Ed.), New forms of citizen participation: Normative implications (pp. 97-112). Baden-Baden: Nomos.

Karlsson, M. (2011). Connecting citizens to the European parliament: E-consultations as a tool for political representation. In Z. Sobaci (Ed.), E-Parliament and ICT-based legislation: Concept, experiences and lessons (pp. 80-102). Hershey, PA: IGI-Global.

Kaufmann, B. (2012). Transnational 'Babystep': The European citizens' initiative. In M. Setala \& T. Schiller (Eds.), Citizens' initiatives in Europe. Procedures and consequences of Agendasetting by citizens (pp. 101-116). Basingstoke: Palgrave Macmillan. 
Kersting, N. (2005). The quality of political discourse: Can e-discussion be deliberative? Paper presented at the British Political Studies Association Annual Conference 5-7 April, Leeds.

Kersting, N. (2013). Online participation: from 'invited' to 'invented' spaces. International Journal of Electronic Governance, 6(4), 270-280.

Kersting, N., \& Baldersheim, H. (Eds.). (2004). Electronic voting and democracy. A comparative analysis. London: Palgrave.

Kies, R., \& Nanz, P. (2013). Introduction. In R. Kies \& P. Nanz (Eds.), Is Europe listening to us? Success and failure of EU citizen consultations (pp. 1-16). Farnham: Ashgate.

Kies, R., Leyenaar, M., \& Niemöller, K. (2013). European citizen's consultation: A large consultation on a vague topic. In R. Kies \& P. Nanz (Eds.), Is Europe listening to us? Success and failure of EU citizen consultations (pp. 59-78). Farnham: Ashgate.

Kim, S., \& Lee, J. (2012). E-participation, transparency, and trust in local government. Public Administration Review, 72(6), 819-828.

Kinney, B. (2012). Deliberation's contribution to community capacity building. In T. Nabatchi, J. Gastil, M. Leighninger, \& G. M. Weiksner (Eds.), Democracy in motion: Evaluating the practice and impact of deliberative civic engagement (pp. 1-23). New York, NY: Oxford University Press.

Kitsing, M. (2014). Rationality of internet voting in Estonia. Electronic government and electronic participation. In M. F. W. H. A. Janssen, et al. (Eds.), Electronic government and electronic participation joint proceedings of ongoing research, posters, workshop and projects of IFIP EGOV 2014 and ePart 2014 (pp. 55-64).

Knaut, A. (2013). Die Europäische Bürgerinitiative - innovativ, transnational und demokratisch? Paper zum Panel "Demokratische Innovationen im Kontext gesellschaftlicher Diversität", Politik der Vielfalt. Drei-Länder-Tagung der ÖGPW, DVPW und SVPW, 19.-21. September 2013, Universität Innsbruck.

Knobloch, K. R., \& Gastil, J. (2015). Civic (Re)socialisation: The educative effects of deliberative participation. Politics, 35(2), 183-200.

Knobloch, K. R., Gastil, J., Reedy, J., \& Walsh, K. C. (2013). Did they deliberate? Applying an evaluative model of democratic deliberation to the Oregon citizens' initiative review. Journal of Applied Communication Research, 41(2), 105-125.

Koc-Michalska, K., Gibson, R., \& Vedel, T. (2014). Online campaigning in France, 2007-2012: Political actors and citizens in the aftermath of the Web.2.0 evolution. Journal of Information Technology and Politics, 11(2), 220-244.

Lampe, C., Zube, P., Lee, J., Park, C. H., \& Johnston, E. (2014). Crowdsourcing civility: A natural experiment examining the effects of distributed moderation in online forums. Government Information Quarterly, 31(2), 317-326.

Leighninger, M. (2012). Mapping deliberative civic engagement. In T. Nabatchi, J. Gastil, M. Leighninger, \& G. M. Weiksner (Eds.), Democracy in motion: Evaluating the practice and impact of deliberative civic engagement (pp. 1-23). New York, NY: Oxford University Press.

Liberini, F., Redoano, M., Russo, A., Cuevas, A., \& Cuevas, R. (2018). Politics in the Facebook Era. Evidence from the 2016 US Presidential Elections. Online Working Paper Series No. 389, Centre for Competitive Advantage in the Global Economy, The University of Warwick. Accessed January 23, 2019, from https://warwick.ac.uk/fac/soc/economics/research/cen tres/cage/manage/publications/389-2018_redoano.pdf

Lim, S., \& Oh, Y. (2016). Online versus offline participation: Has the democratic potential of the internet been realized? Analysis of a participatory budgeting system in Korea. Public Performance and Management Review, 39(3), 676-700.

Lindner, R. (2012). Wie verändert das Internet die Demokratie? Gesellschaft, Wirtschaft, Politik $(G W P), 61(4), 517-525$.

Lindner, R., \& Riehm, U. (2011). Broadening participation through e-petitions? An empirical study of petitions to the German parliament. Policy and Internet, 3(1, Article 3), 1-23. 
Lindner, R., Aichholzer, G., \& Hennen, L. (Eds.). (2016). Electronic democracy in Europe. Prospects and challenges of e-publics, e-participation and e-voting. Cham: Springer International.

Lironi, E. (2016). Potential and challenges of E-participation in the European Union. Study for the AFCO Committee, European Parliament, Policy Department for Citizens' rights and constitutional affairs. Brussels: European Parliament.

Loukis, E., \& Wimmer, M. (2012). A multi-method evaluation of different models of structured electronic consultation on government policies. Information Systems Management, 29(4), 284-294.

Loveland, M. T., \& Popescu, D. (2011). Democracy on the web: Assessing the deliberative qualities of internet forums. Information Communication and Society, 14(5), 684-703.

Lu, Y., Heatherly, K. A., \& Lee, J. K. (2016). Cross-cutting exposure on social networking sites: The effects of SNS discussion disagreement on political participation. Computers in Human Behavior, 59, 74-81.

Mahrer, H., \& Krimmer, R. (2005). Towards the enhancement of e-democracy: Identifying the notion of the 'middleman paradox'. Information Systems Journal, 15(1), 27-42.

Markussen, R., Ronquillo, L., \& Schürmann, C. (2014). Trust in internet election observing the Norwegian decryption and counting ceremony. Conference Paper, Electronic Voting: Verifying the Vote (EVOTE), 2014 6th International Conference.

McGaley, M., \& McCarthy, J. (2004). Transparency and e-voting - Democratic vs. commercial interests. In A. Prosser, \& R. Krimmer (Eds.), Proceedings of the 1st International Workshop on Electronic Voting in Europe (pp. 153-163). Lecture Notes in Informatics.

Mechant, P., Stevens, I., Evens, T., \& Verdegem, P. (2012). E-deliberation 2.0 for smart cities: A critical assessment of two 'idea generation' cases. International Journal of Electronic Governance, 5(1), 82-98.

Medaglia, R. (2011). eParticipation research: A longitudinal overview. In E. Tambouris, A. Macintosh, \& H. DeBruijn (Eds.), Electronic Participation, Epart, Vol. 6847 (pp. 99-108).

Medaglia, R. (2012). eParticipation research: Moving characterization forward (2006-2011). Government Information Quarterly, 29(3), 346-360.

Miori, V., \& Russo, D. (2011). Integrating online and traditional involvement in participatory budgeting. Electronic Journal of e-Government, 9(1), 41-57.

Mkude, C. G., Perez-Espes, C., \& Wimmer, M. A. (2014). Participatory budgeting: A framework to analyze the value-add of citizen participation. In Proceedings of 47th International Conference on System Sciences (HICSS), 6-9 Jan 2014, Waikoloa, HI, pp. 2054-2062.

MLGRD, Ministry of Local Government and Regional Development. (2012). Summary of the ISF report: Ministry of Local Government and Regional Development.

Monaghan, E. (2012). Assessing participation and democracy in the EU: The case of the European citizens' initiative. Perspectives on European Politics and Society, 13(3), 285-298.

Murray, M. (2013). Politics at the touch of a button: An evaluation of the first ever Oireachtas (Irish Houses of Parliament) E-consultation. Parliamentary Affairs, 66(3), 597-616. https://doi.org/ $10.1093 / \mathrm{pa} / \mathrm{gsr} 072$.

Organ, J. (2014). Decommissioning direct democracy? A critical analysis of commission decisionmaking on the legal admissibility of European citizens initiative proposals. European Constitutional Law Review, 10(3), 422-443.

OSCE. (2010). Election observation handbook, 6th edn.

OSCE/ODIHR. (2011). Estonia Parliamentary Elections 6 March 2011: OSCE/ODIHR Election Assessment Mission Report. Accessed January 23, 2019, from http://www.osce.org/odihr/ 77557 ? download $=$ true

OSCE/ODIHR. (2012). Swiss Confederation Federal Assembly Elections 23 October 2011: OSCE/ ODIHR Election Assessment Mission Report.

OSCE/ODIHR. (2013). Norway Parliamentary Elections 9 September 2013: OSCE/ODHIR Election Assessment Mission Final Report. 
Pammett, J. H., \& Goodman, N. (2013). Consultation and evaluation practices in the implementation of Internet Voting in Canada and Europe. Ottawa: Elections Canada. Accessed January 23, 2019, from www.elections.ca/res/rec/tech/consult/pdf/consult_e.pdf

Panagiotopoulos, P., Moody, C., \& Elliman, T. (2011). An overview assessment of ePetitioning tools in the English local government. In E. Tambouris, A. Macintosh, DeBruijn, H. (Eds.), Electronic participation, Epart, Vol. 6847, pp. 204-215.

Panopoulou, E., Tambouris, E., \& Tarabanis, K. (2014). Success factors in designing eParticipation initiatives. Information and Organization, 24(4), 195-213. https://doi.org/10.1016/j. infoandorg.2014.08.001.

Parycek, P., Sachs, M., Sedy, F., \& Schossboeck, J. (2014). Evaluation of an E-participation Project: Lessons learned and success factors from a cross-cultural perspective. In E. Tambouris, A. Macintosh, F. Bannister (Eds.), Electronic Participation, Epart. Vol. 8654, pp. $128-140$.

People2power. (2017). Spring Comeback Kid: The European Citizens' Initiative. Accessed January 23, 2019, from http://www.people2power.info/insight/spring-comeback-kid-the-european-citi zens-initiative/

Persily, N. (2017). The 2016 U.S. election: Can democracy survive the internet? Journal of Democracy, 28(2), 63-76.

PETI - Committee on Petitions (2015). Report on the activities of the Committee on Petitions 2014, 2014/2218(INI), European Parliament. Accessed January 23, 2019, from http://www.europarl. europa.eu/sides/getDoc.do?pubRef=-//EP//NONSGML+REPORT+A8-2015-0361+0+DOC $+\mathrm{PDF}+\mathrm{V} 0 / / \mathrm{EN}$

Pichler, J. W., \& Kaufmann, B. (Eds.) (2012). Modern transnational democracy. How the 2012 launch of the European Citizen's initiative can change the world. Schriften zur Rechtspolitik, Bd. 33. Wien-Graz: Neuer Wissenschaftlicher Verlag.

Pimentel Walker, A. P. (2016). Self-help or public housing? Lessons from co-managed slum upgrading via participatory budget. Habitat International, 55, 58-66.

Quittkat, C. (2011). The European commission's online consultations: A success story? Journal of Common Market Studies, 49(3), 653-674.

Quittkat, C., \& Finke, B. (2008). The EU commission consultation regime. In B. Kohler-Koch, D. De Bièvre, \& W. Maloney (Eds.), Opening EU-Governance to Civil Society. Gains and Challenges, CONNEX Report Series No 05, University of Mannheim, Mannheim Centre for European Social Research (MZES), Mannheim, pp. 183-222. Accessed January 23, 2019, from http://www.mzes.uni-mannheim.de/projekte/typo3/site/fileadmin/BookSeries/Volume_Five/ Chapter08_Quittkat_Finke.pdf

Riehm, U., Coenen, C., Lindner, R., \& Blümel, C. (2009). Bürgerbeteiligung durch E-Petitionen. Analysen von Kontinuität und Wandel im Petitionswesen. Berlin: Edition Sigma.

Riehm, U., Böhle, K., \& Lindner, R. (2014). Electronic petitioning and modernization of petitioning systems in Europe. Technology Assessment Studies Series - 6, TAB Office of Technology Assessment at the German Bundestag.

Rikken, K. (2011, February 10). Student finds flaw in e-voting, seeks nullification of result. Accessed January 23, 2019, from https://news.err.ee/99405/student-finds-flaw-in-e-votingseeks-nullification-of-result

Röcke, A. (2014). Framing citizen participation. Participatory budgeting in France, Germany and the United Kingdom. London: Palgrave.

Ruesch, M., \& Märker, O. (2012). Real name policy in E-participation. The case of Gütersloh's second participatory budget. Paper presented at CeDEM 2012, Krems, Austria, May 3-4.

Rumbul, R. (2014). In the digital era, political activism can be individual as well as collective. Retrieved September 2016, from Democratic Audit UK. Accessed on January 23, 2019, from http://www.democraticaudit.com/2014/12/16/in-the-digital-era-political-activism-can-be-indi vidual-as-well-as-collective

Russmann, U. (2011). Targeting voters via the Web. A comparative structural analysis of Austrian and German party websites. Policy and Internet, 3(3), Article 3. 
Rustema, R. (2014). Why the ECI needs a community-developed online collection system. In C. Berg, \& J. Thomson (Eds.), An ECI that works! Learning from the first two years of the European Citizens' Initiative. The ECI Campaign (pp. 104-106). Accessed January 23, 2019, from www.ecithatworks.org/wp-content/uploads/2014/04/An_ECI_That_Works.pdf

Ryfe, D. M., \& Stalsburg, B. (2012). The participation and recruitment challenge. Democracy in motion: Evaluating the practice and impact of deliberative civic engagement.

Sál, K. (2015). Remote Internet voting and increase of voter turnout: Happy coincidence or fact? The case of Estonia. Masaryk University. Journal of Law and Technology, 9(2), 15-32.

Sangsari, M. (2013). The European citizens' initiative: An early assessment of the European Union's new participatory democracy instrument, Policy Paper, Canada-Europe Transatlantic Dialogue: Saurugger, S. (2010): The social construction of the participatory turn: The emergence of a norm in the European Union. European Journal of Political Research, 49(4), 471-495.

Santos, H. R., \& Tonelli, D. F. (2014). Possibilities and limits of E-participation: A systematic review of E-democracy. XXXVIII Encontro de ANPAD, Rio de Janeiro, 13-17 September.

Saurugger, S. (2010). The social construction of the participatory turn: The emergence of a norm in the European Union. European Journal of Political Research, 49(4), 471-495.

Scherer, S., \& Wimmer, M. A. (2014). Trust in e-participation: Literature review and emerging research needs. Paper presented at the ACM International Conference Proceeding Series.

Schneider, S. (2018). Bürgerhaushalte in Deutschland: Individuelle und kontextuelle Einflussfaktoren der Beteiligung. Wiesbaden: Springer VS.

Schumann, S., \& Klein, O. (2015). Substitute or stepping stone? Assessing the impact of low-threshold online collective actions on offline participation. European Journal of Social Psychology, 45(3), 308-322.

Serdült, U., Germann, M., Mendez, F., Portenier, A., \& Wellig, C. (2015). Fifteen years of internet voting in Switzerland: History, governance and use. In Terán, L., \& Meier, A. (Eds.), ICEDEG 2015: Second International Conference on eDemocracy and eGovernment, Quito, Ecuador, 8-10 April 2015, IEEE Xplore CFP1527Y-PRT, pp. 126-132. Accessed January 23, 2019, from https://doi.org/10.1109/ICEDEG.2015.7114482

Sintomer, Y., Carsten Herzberg, C., \& Röcke, A. (2008). Participatory budgeting in Europe: Potentials and challenges. International Journal of Urban and Regional Research, 32(1), 164-178.

Sintomer, Y., Herzberg, C., \& Röcke, A. (2010). Der Bürgerhaushalt in Europa - eine realistische Utopie? Wiesbaden: VS Verlag für Sozialwissenschaften.

Siu, A., \& Stanisevski, D. (2012). Deliberation in multicultural societies. In T. Nabatchi, J. Gastil, M. Leighninger, \& G. M. Weiksner (Eds.), Democracy in motion: Evaluating the practice and impact of deliberative civic engagement. New York, NY: Oxford University Press.

Sivonen, E. (2011). Supreme court rejects last voter complaint. News.err.ee, 21.3.2011. Accessed January 23, 2019, from http://news.err.ee/99529/supreme-court-rejects-last-voter-complaint

Smith, G. (2013). Designing democratic innovations at the European level: Lessons from the experiments. In R. Kies \& P. Nanz (Eds.), Is Europe listening to us? Success and failure of EU citizen consultations (pp. 201-216). Farnham: Ashgate.

Spada, P., Mellon, J., Peixoto, T., \& Sjoberg, F. M. (2016). Effects of the internet on participation: Study of a public policy referendum in Brazil. Journal of Information Technology and Politics, 13(3), 187-207.

Springall, D., Finkenauer, T., Durumeric, Z., Kitcat, J., Hursti, H., MacAlpine, M., \& Halderman, J. A. (2014). Security analysis of the Estonian internet voting system. In CCS'14: 21st ACM Conference on Computer and Communications Security (pp. 703-715).

Starskaya, M., \& Çagdas, Ö. (2012). Analysis of the online collection software provided by the European Commission for the European Citizens' Initiative. Working Papers on Information Systems, Information Business and Operations, 01/2012. Vienna University of Economics and Business, Vienna. Accessed January 23, 2019, from http://epub.wu.ac.at/3643/1/Binder1_(2). pdf 
Stein, R., \& Wenda, G. (2014). The Council of Europe and e-voting: History and impact of Rec (2004)11. Conference Paper, International Conference on Electronic Voting EVOTE2014.

Strandberg, K. (2015). Designing for democracy?: An experimental study comparing the outcomes of citizen discussions in online forums with those of online discussions in a forum designed according to deliberative principles. European Political Science Review, 7(3), 451-474.

Strandberg, K., \& Grönlund, K. (2012). Online deliberation and its outcome-evidence from the virtual polity experiment. Journal of Information Technology and Politics, 9(2), 167-184.

Talpin, J. (2012). When democratic innovations let the people decide. An evaluation of co-governance experiments. In B. Geissel \& K. Newton (Eds.), Evaluating democratic innovations: Curing the democratic malaise? (pp. 184-206). New York: Routledge.

Thomson, J. (2014). What didn't happen with the European citizens' initiative. . . and what did. In C. Berg, \& J. Thomson (Eds.), An ECI that works! Learning from the first two years of the European Citizens' Initiative. The ECI Campaign (pp. 73-76). Accessed January 23, 2019, from www.ecithatworks.org/wp-content/uploads/2014/04/An_ECI_That_Works.pdf

Tiburcio, T. (2015). The right to petition. Study for the PETI Committee. Directorate General for Internal Policies, Policy Department C: Citizens' Rights and Constitutional Affairs, Brussels. Accessed January 23, 2019, from http://www.europarl.europa.eu/RegData/etudes/STUD/2015/ 519223/IPOL_STU(2015)519223_EN.pdf

Tomkova, J. (2009). E-consultations: New tools for civic engagement or facades for political correctness? European Journal of ePractice, 7, March.

Toots, M., Kalvet, T., \& Krimmer, R. (2011). Success in eVoting - Success in eDemocracy? The Estonian Paradox. Accessed January 23, 2019, from http://ssrn.com/abstract=2757704

Torcal, M., \& Maldonado, G. (2014). Revisiting the dark side of political deliberation the effects of media and political discussion on political interest. Public Opinion Quarterly, 78(3), 679-706.

Towner, T. L., \& Dulio, D. A. (2012). New media and political marketing in the United States: 2012 and beyond. Journal of Political Marketing, 11(2), 95-119.

van Dijk, J. A. G. M. (2012). Digital democracy: Vision and reality. In I. Snellen, W. Thaens, \& W. van de Donk (Eds.), Public administration in the information age: Revisited (pp. 49-61). Amsterdam: IOS-Press.

Vassil, K., \& Weber, T. (2011). A bottleneck model of e-voting. New Media and Society, 13(8), $1336-1354$.

Venice Commission. (2003). Code of good practice in electoral matters: Guidelines and explanatory report: Adopted by the Venice Commission at its 51 st and 52nd sessions (Venice, 5-6 July and 18-19 October 2002). Opinion no. 190/2002. Strasbourg.

Vinkel, P. (2012). Internet voting in Estonia. In P. Laud (Ed.) Information security technology for applications (pp. 4-12). Springer.

Volodin, D. S. (2014). Participative budgeting as an effective approach for local budgets distribution improvement in Ukraine. Actual Problems of Economics, 160(1), 373-379.

Wang, X., \& Wan Wart, M. (2007). When public participation in administration leads to trust: An empirical assessment of managers' perceptions. Public Administration Review, 67(2), 265-278.

Ward, S., Gibson, R., \& Nixon, P. (2003). Parties and the Internet. In R. Gibson, P. Nixon, \& S. Ward (Eds.), Political parties and the internet. Net gain? (pp. 11-38). London/New York: Routledge.

Weiksner, G. M., Gastil, J., Nabatchi, T., \& Leighninger, M. (2012). Advancing the theory and practice of deliberative civic engagement. In T. Nabatchi, J. Gastil, M. Leighninger, \& G. M. Weiksner (Eds.), Democracy in motion: Evaluating the practice and impact of deliberative civic engagement (pp. 1-16). Oxford/New York: Oxford University Press.

Wolchok, S., Wustrow, E., Isabel, D., \& Halderman, J. A. (2012). Attacking the Washington, D.C. Internet Voting System. In A. D. Keromytis (Ed.), Financial cryptography and data security (pp. 114-128). Berlin: Springer.

Woolley, S. C., \& Guilbeault, D. (2017). Computational propaganda in the United States of America: Manufacturing consensus online. In S. Woolley, \& P. N. Howard (Eds.) Working Paper 2017.5. Oxford: Project on Computational Propaganda. Accessed January 23, 2019, from http://blogs.oii.ox.ac.uk/politicalbots/wp-content/uploads/sites/89/2017/06/Comprop-USA.pdf 
Woolley, S. C., \& Howard, P. N. (2016). Automation, algorithms, and politics. Political communication, computational propaganda, and autonomous agents - Introduction. International Journal of Communication, 10, 4882-4890.

Woolley, S. C., \& Howard, P. N. (eds.) (2018). Computational propaganda. Political parties, politicians, and political manipulation on social media. Oxford Studies in Digital Politics, Oxford University Press.

Wright, S. (2012). Assessing (e-)democratic innovations: "Democratic goods" and downing street e-petitions. Journal of Information Technology and Politics, 9(4), 453-470.

Wright, S. (2016). 'Success' and online political participation: The case of Downing Street E-petitions. Information Communication and Society, 19(6), 843-857.

Yang, M. (2013). Europe's new communication policy and the introduction of transnational deliberative citizen's involvement projects. In R. Kies \& P. Nanz (Eds.), Is Europe listening to us? Success and failure of EU citizen consultations (pp. 17-34). Farnham: Ashgate.

Zhang, W., Xu, X., Zhang, H., \& Chen, Q. (2016). Online participation chaos: A case study of Chinese government-initiated e-polity square. International Journal of Public Administration, $1-8$.

Open Access This chapter is licensed under the terms of the Creative Commons Attribution 4.0 International License (http://creativecommons.org/licenses/by/4.0/), which permits use, sharing, adaptation, distribution and reproduction in any medium or format, as long as you give appropriate credit to the original author(s) and the source, provide a link to the Creative Commons licence and indicate if changes were made.

The images or other third party material in this chapter are included in the chapter's Creative Commons licence, unless indicated otherwise in a credit line to the material. If material is not included in the chapter's Creative Commons licence and your intended use is not permitted by statutory regulation or exceeds the permitted use, you will need to obtain permission directly from the copyright holder.

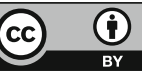

